\title{
A STUDY ON EXPERIMENTAL ACOUSTIC TRAUMA IN ANIMALS WITH THE INJURY OF KIDNEYS OR LIVER
}

\author{
$\mathrm{By}$ \\ Y. KIKUCHI \\ From the Department of Oto-Rhino-Laryngology, School of Medicine, \\ Osaka University (Director: T. Hasegawa)
}

Guinea pigs were treated with $\mathrm{HgCl}_{2}$ or Cantharidin for the kidneys and $\mathrm{CCl}_{4}$ or dl-Ethionine for the liver, so that no histopathological changes of the auditary organ developed, and the acoustic stimuli were given. The treated animals were asumed to have developed unhealthy intrinsic factors, the ear being Locus minoris resistantae to the acoustic trauma.

The acoustic stimuli loaded were 120 Phon at $2000 \mathrm{cps}$ repeated for 10 day (for 2 hours every other day) or 110 Phon repeated for 10 days (for 2 hours daily). It was confirmed that the acoustic stimuli caused no pathological changes of the auditoryorgan.

The results obtained were as follows:

1) When the animals with the injury of kidneys were exposed to the acoustic stimuli, degeneration of cells were observed at the 2 nd turn of Corti's organ.

2) When the animals with the injury of liver were exposed to the acoustic stimuli, degeneration of cells were observed at the 2nd turn of Corti's Organ.

3) Preyer's reflex test showed an obvious impairment in the high tone region.

It was concluded that the susceptibility to acoustic trauma was increased in those animals with the injury of kidneys or liver.

\section{腎・肝障碍動物の音響受傷性に関する実験的研究}

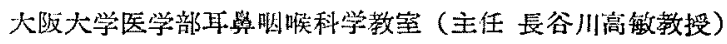

$$
\text { 医学士 菊渠唐 三 }
$$

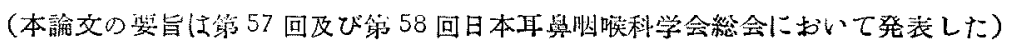

\begin{tabular}{|c|c|}
\hline & 次 \\
\hline 舄1章 綃 & 薑 \\
\hline \multicolumn{2}{|c|}{ 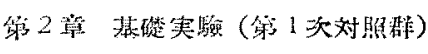 } \\
\hline \multicolumn{2}{|c|}{ 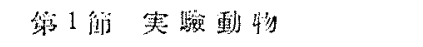 } \\
\hline \multicolumn{2}{|c|}{ 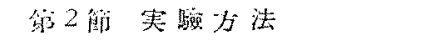 } \\
\hline 第 1 項 & 吾的筧生装置 \\
\hline 第 2 項 & 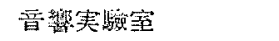 \\
\hline 第了項 & 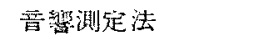 \\
\hline 第 4 項 & 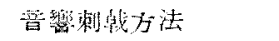 \\
\hline
\end{tabular}

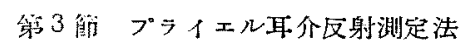

第 4 始 標本作成法

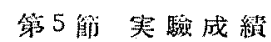

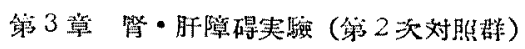

苟 1 解 㫮障碍法

第 1 項 㐿湬投与法

第2項 カンタリギン投与法

第2 2 解 䀒障碍法

穿1 项 四塩化策素投与法 
第 2 頊 メチォニン投与法

第 3 简 奏驗成綪

第１項 筒匴碍群

第 2 項 肝障 碍 群

第 4 章 吾然制戟負荷実驗

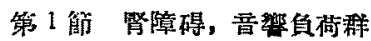

第 1 賈 累事投与群

第 2 頊 カンタリヂン投与群

第 2 筑 肝障碍，吾繁免荷群

第 1 項 四塩化炭素投与砧

第 2 項 エチオンン投与群

第 5 章 総括全びに涪按

第6 音 結語

主裂参考文献

\section{第1章 緒喜}

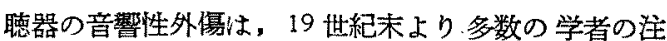
目する所となり，幾多先賢の詳細な臨床的，奏験的研究 によつて，今世紀半ばには殆んどその全貌が究め尽され たかの如き䮭がある。

しかし乍ら，現在な括未解決の問題もあり，例えば音 響性外傷の受傷性, 個体差, 非健康体の音響受傷性等に 関しては未だ不明のま〉で放置されている。

稂つて先人の業績を㕍頁れば，従来これら音響性外賃汇 関する研究は，臨床的には音響以外に難聴をきたし得る 疾患は除外されるのが常であり，害験的にも全て健康動 物を用いてなされたるのであつた・即ちこれらは単に音 䪭剌战之云弓一外因的要素による聴器障碍であつて，対 象たる個体にある内因的要素，换言すれば，何等かの疾 患方至は潜在性病変を有する場合に，㧽体の音響受賃性 がいかに变化するかに就いての明碲な研究は無く，僅か に臨床上の経験及び統計的観察によつて，その受匴性の 昂進が推諭されてきたに過ざない。

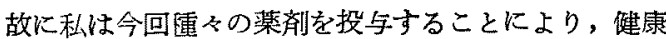
動物の音響受傷に対する内因的要素たる腎・肝障碍を生 ぜしめ，これに一定の音響刺㦸を負荷して，従来なされ きた臨床的推論を军験的に証明し，且つ恥器病変の発現 並びに様相の訮細を究めんとして，以下の実験を企図し た。

\section{第 2 章 基礎実験（第 1 次対照群）}

第 1 節 実墟動物

実験動物にはプンイェル耳介反射測定に最も適した海

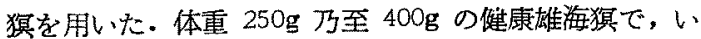
つれる耳镜検㚗により耳坧無く, 鼓膜正常, プライェル
耳介区射良好なるので，20 秒 10 回転の回転後眼振を測 定し，前庭機能に異常の無いことを確めた。

第 2 節 実験力法

第 1 項 音響発生装置

音源に柱永島製 51-A オーヂオメーターを使用し， これを山水HV6型増幅器により増幅,與西電譏製30Watt Reflex Horn Speaker に連結した・これより $2000 \mathrm{cps}$ 110，120 phon の音蠁を発生せしめた。

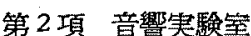

垁歌室には阪大耳鼻咽喉科教室の防音室を使用した。 この実験室は大きさ $2.25 \mathrm{~m} \times 2.52 \mathrm{~m} \times 2.62 \mathrm{~m}$, 容積 14.85 $\mathrm{m}^{3}$, 壁は各面とも木挅，ガラスウール，木板，鉄板，ガ ラスゥール, 木板, ペンキ塗りテックス張りで，一面に 二重屝附の出入口を設け副室に連絡している。

第 3 項 音響测定法

スピーカーより常に一定強度の音響を発生せしめるた

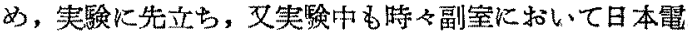
子測器製の Sound level meterを用いて刺戱音響を測 定した。

第4 項 音響刺战方法。

刺战音響は，標本作成後聴器所見を検索するに便なる よう，蝸牛殼第 2 回転にその感受部位を有する 2000cps を選び，刺㦸音響の強度及び持続時間には最も注意を払 ひ，それのみでは聴器に 何等の病的変化を生じないゃ ろ，先人の実験を参考にし，又種々の強度，時間で基礎 的な予蛹夷験を綿密に行い，結局

1) 120phon て 1日2時間，隔日K10回

2) 110phon で毎日 2 特間，道続 10 日間 を用いた：動物を金網箱の中に入れ，これをスピーカー より $1 \mathrm{~m}$ 離して並べ，音響刺钱を行つた。

第3節 プラィェル耳介反射湘定法

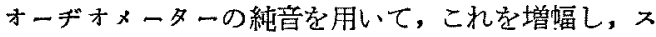
ビーカーに婵絈，動物をスピーカーの前 $30 \mathrm{~cm}$ に置き， $500,1000,2000,4000,8000 \mathrm{cp}$ 各周波別以 耳介の最少 限の反射運動をるつてその最低反心值とした。

音響刺钱開始前の最低及伈值を基とし，実駼終了後 3 日目の值と比籍して，ォーヂオグラムを作成した。

第 4 節 標本作成法

実験終了後，なお3日間毁物を飼育し，ブライエル耳 介反射，回転後眼振及び体重ての他の全身所見を観祭 し，これをWittmaack 氏液にて 生体固定を行つた。 聴器及び腎・肝の標本作成は山川氐記載の方法により， ツェロイヂン包埋後 $10 \sim 15 \mu$ の連続切片とし，へマト 
キシリン・东ォジシ重染色を行つだ。

第 5 笛 缹験成績

A) 臨厓所見

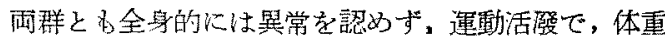
は順調に增加した・プライエル耳介反射は音響刺僦中は 低下していたが，奏験終了後 3 日目には，オーギオグラ

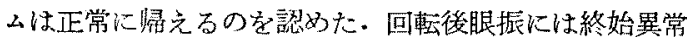
を諰めなかつた。

B) 聴器の病理組穖学的所見

1) $2000 \mathrm{cps}, 120$ phon で1日2持間，隔日に 10 回音響刺锤した群

全例に叔いて外耳及び中耳には異常を認めなかつた。

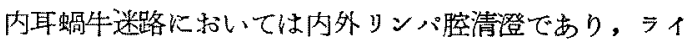
スネル膜は全国転正常位に祭張し、コルチ器にも全回転 異常を認めなかつた・即っ外毛細胞は輸廍境界ともに鮮 明て核に異常典く 聴毛も存寸る.内毛細胞にも異常を 認めない、ダイテルス,ヘンゼン，タラウデウス各細胞

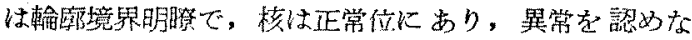
い内外柱細胞, 基磷膜に藷明な屈曲無くトンネル腔 は清澄で，腔内神経線維は明睧に認められる。その他内

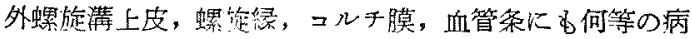
的所見を認めなかつた。ローゼンタール管内神経細胞及 び螺旋神経節細跑も全回転において異常を認めなかつ た.内耳前庭迷路は全域に亘つて異常を認めなかつた。

2) $2000 \mathrm{cps}$, 110 phon で每日2時間，連続

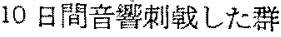

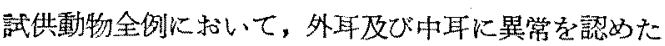
ものは無かつた。内耳の蛤牛迷路では内外リッパ腹清澄 であり、コルチ器は全回転に扣いて変化を認めなかつ た・即ち内外毛細胞正常で，その他の卖持細胞にも異

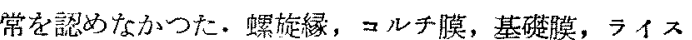
ネル膜，血管条にも病变を認めなかつた。ローゼンター 儿管，螦旋神経節稩胞も全回転に異常を諗めなかつた。 前庭迷路恃全域正常で方つた。

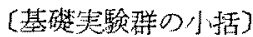

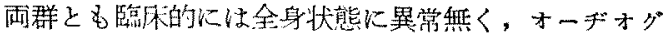

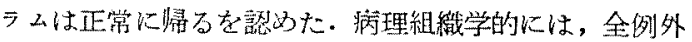

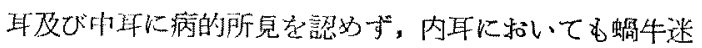
路つ全回枟に二ルチ器, 螺旋神経節細胞, 只の他の異常

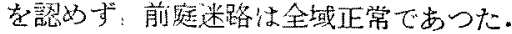

要するに，厸の選んだ刺战音響でこの㭙期において は, 動物の聴器に臨床的; 病理組織学的に何等の病的異 常所見を認好ない，换言すれれば，斯る音響によつては健

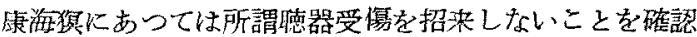
した。

な招これら基礎奏験群においては，病理組織学的に， 腎及び肝には何等の異常所見を認めなかつた。

上上，本音響刺踤のみの群を第１次対䀡群とした。

\section{第3 章 堅・肝障碍実験（第 2 次対照群）}

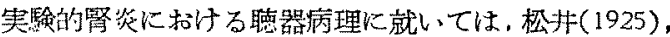

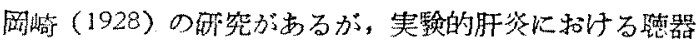

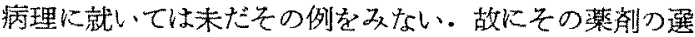

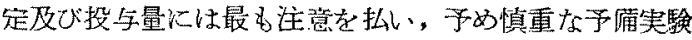
を行い，その結果次の如く決めた。

な和実験動物，プライェル耳取射測定法及び䊈本作 成法は，第 2 章第 1 次対照群に準ずるため，この章では 省略した。

第 1 筑 㹂障碍法

第 1 項 昇乘投与法

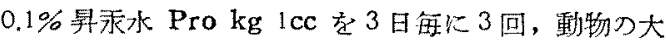

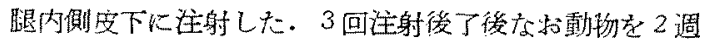
間乃琹 5 週間飼姢した。

第2 項 カンタリヂン投与法

カンタリデンをオレフ油に溶解，0.2\%溶液とし, 「ro kg lcc 3 日每に3回，動物の大眼内則皮下に注射L， 3 回注射終了後な括 2 週間餇育した。

第2 節 肝障碍法

第 1 頊 四塭化宸素投与法

四程化炭素をホレフ油に溶解，0.5\%溶液とし，Pro

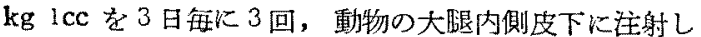

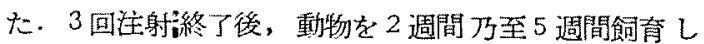
た.

第 2 項 エチネニン投与法

dl-Ethionine $92.5 \%$ 生理的食塩水溶液 Pro kg lcc を毎日1回連続 10 日間, 動物の腹腔内注射し, 10 回 注射終了後 3 日間注司青した。

第3 節 金駼成績

第 1 項鳌障碍群

A) 隐床所睍

萃我投与群，カンタリデン投与群とるに全穿的には著 明な障碍を認めず，体重は一洔的に淢少するものがあつ たが間多無く回復し，上記の如く所定期間闹青倦，生体

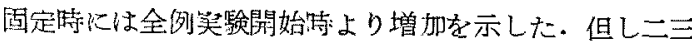
薬剂往射部位に硬結むるいは潰㿑を形成するものがあつ た。

プタイエル耳介反射には全然異常を認めず，回転後眼 
振も正常であつた。

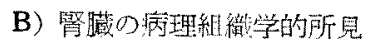

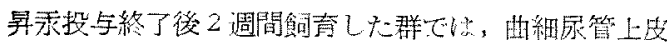

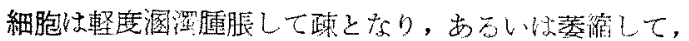
胞体の輪到境界ともに不鮮明となる. 管腔俚报張し, 腔

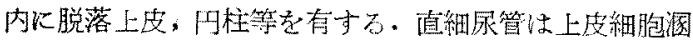

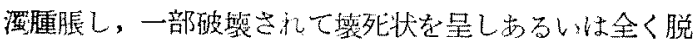

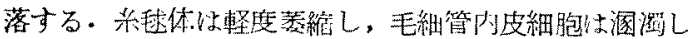

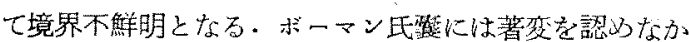
つた。

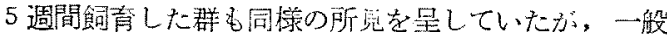

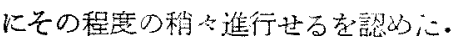

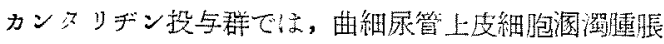

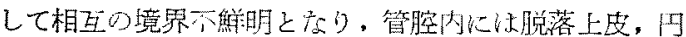

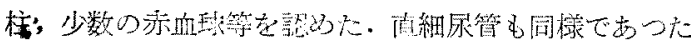

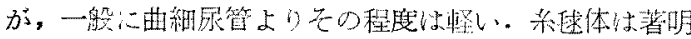

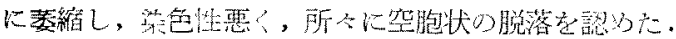

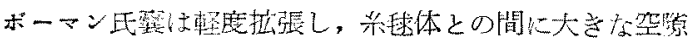

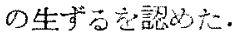

C) 聴器の病理組糡学的所見

昇秉埕与群，カンタリヂン投与群ともに大差想く，全

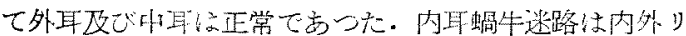
ンパ空清澄であり，ライスネル膜は谷回転正常位に繁張

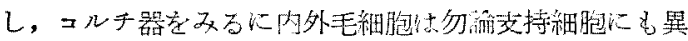

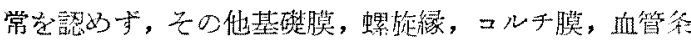
も正常ですつた・トンホル腔内神絟線維, ロービンタ一

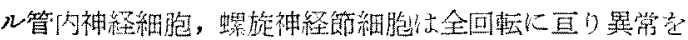
誌ひなかつた。前庭迷路は全域正常であつた。

身項 胙障碍群

A) 踣床所胃

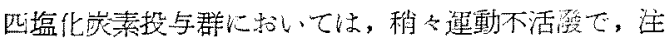

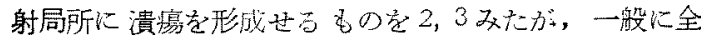

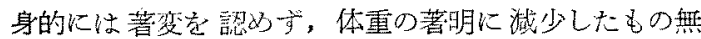
く、多く恃徐比回した。

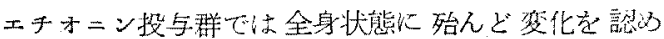

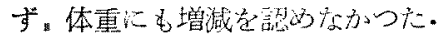

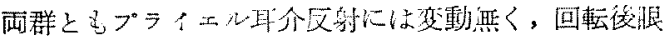

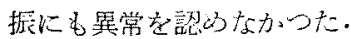

B) 聶缄の病㻎組織学的所晃

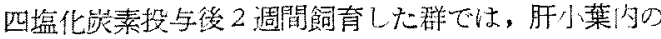
細胞配列乱れ，相它の境界不鮮明となり，中心静脈圊辺

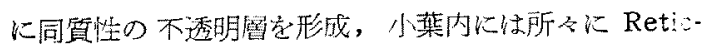
ulumzellen の漫潤及び空腔形成を諗めた。

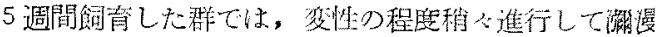

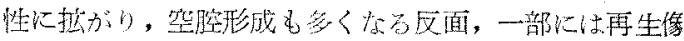

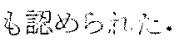

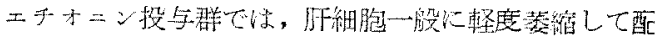

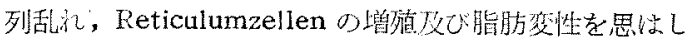

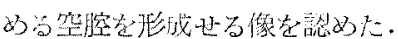

C) 恥器の病理組織学的所㫕

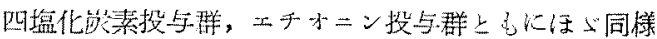
の所晃を呈するのて総括して述べれば，外上及ざけ耳に

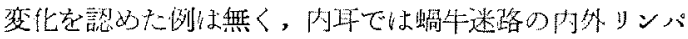

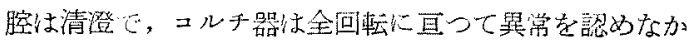

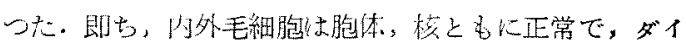
テルス, ヘンビン.タラッヂウス墸細胞, 内外柱細胞等 攵持細胞电正常で方り，トンネル膑内神経楾維は明瞭に

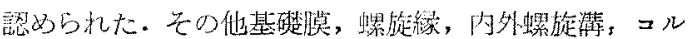

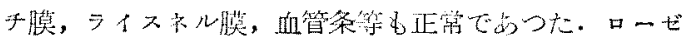

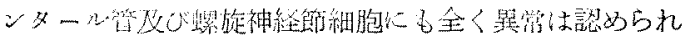

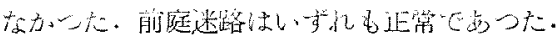

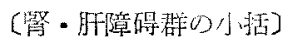

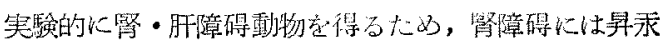

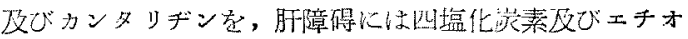

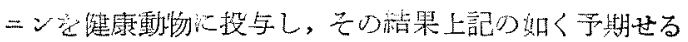

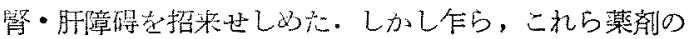

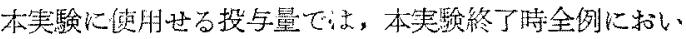

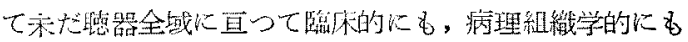

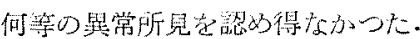

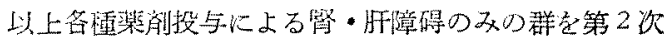

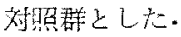

\section{第 4 章 音響剌戟負荷実験}

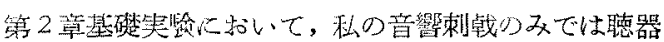

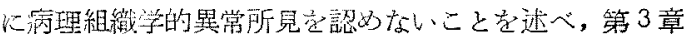

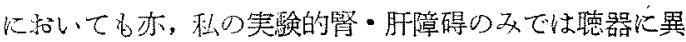
常新認めないこと家述心゙た。

そこで，㯖器に異常を生じない、程度の劉・䀒障碍を持

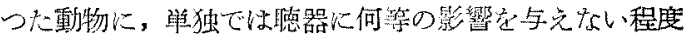

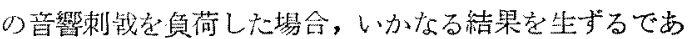

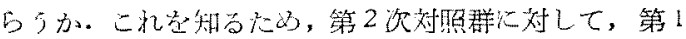

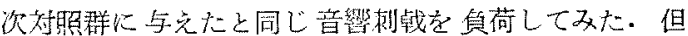

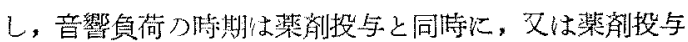
終了後 3 画間埕育してから行つた。その詳細は备実験群 について还べた。

楽剂投与前，音響負荷の前列び実験終了後 3 日目にプ ライール耳介反射起測定し、オーヂオダラムを作成し 
た・勿論同時に回転後眼振を湘定し，全身状態は常に観 察を急らなかつた．標本作成法は第 2 章第 4 節に 同じ く、倩・肝の病理組織学的所見は第 3 章第 3 節に述べた 通りであるので,こっでは割愛した。

第 1 節 腎障碍, 音響負荷群

第 1 項 昇永投与群

I) 舁录投与終了後 3 日目より 音響刺钱 (2000 cps 120phon 2 時間，滆日 10 回）を負荷した群

A) 阽床所見

第 2 次対照群同様全身状態似著変定認好す，体重減 少は一時的で，外くは寒駼開始特上り増加を示した。矢 験終了後 3 日目のプライエル耳开反射より作成したオー ヂオグラムは第 1 図の如く, 水平型あるいは高音漸塗型

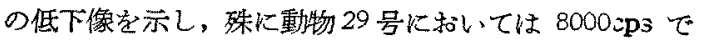
ブライェル耳取射の消失を認めた。回転後眼振による 前莛機能㭘查では，終始何等の珙常を認めなかつた。

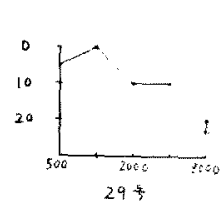

295

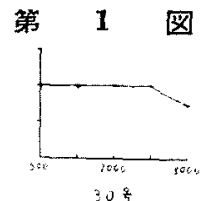

30 옥

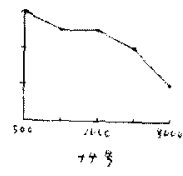

B) 聴器の病理組織学的所見

29 号 (両側) 外耳及び 中耳に認むべき病变は無かつ た.内耳螖牛迷路の内外リンパ腔は清澄である、マルチ 器は基礎回蒜に扎、ては全く異常を認めないが，第2 回 転，殊火气の中央部に著明な变性像が奴られた。即ちこ の部ではロルチ器は全く固有の形熊を失ひ，基䅋莫上に 扁平な一留心製構造物を留め，その中に核の散在するを 認めた。内外蛨旋清上皮子極めて菲薄な同質性物質と化 し，基整膜下細胞群は眯となり核の配列が乱れる・コル チ膜は中央より下方に屈曲するが，その延長のクチク ラ.蛿旋緑に著变は無い.血管条は上皮細胞萎縮して柾 となり，毛細管の脑張が認められ，全体に染色性が恶 いライスネル膜は正常位に在り異常を想めない、ロー ゼンタール管内神絓細胞はや〉眯となるが，その配列に 異常は無い、螺旋神経節細胞は一部胞体の軽度琴縮し細 胞間陵や」蹯となる所もるるがチグロイドの配列に異 常無く、核も正常で著変を想めない，第了回転以上には 異常を認めない，前庭迷路は全域に亘り正常であつた。

30 号 (左側) 外耳, 中耳正常. 内耳蝸牛迷路では, ライスネル膜は全回䎐正常位に在り,内外》ンパ腔清澄 であつた・コルテ器の第 2 回転中央部に変性像を認め
た. 即ち外毛細胞の内側 2 列は融解消失して虫食い、状に 空洞を作り，外側のるのは腫脹して眯となり，その核は 萎縮清染する・ダイテルス細胞，ーンゼン細胞は隀晨 し，境界不鮮明で，核は沈下するるのが多い，内外柱は 僅に屈曲する・トンネル腔内は清澄で，腔内神経線維は 認められる・クラゥデゥス細胞は核の配列乱れる他著变

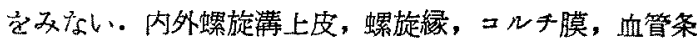
には異常を認めなかつた．基碟回転及び第 3 回転以上に は斯る变性像を認めず，全く正常であつた。螺旋神経節 細胞俚全回転仕亘り何等異常所見を認めなかつた，前莛 迷路は正常であった。

30 号 (右側) 外耳，中耳飞異常を認好ながた。内 耳, 内外リンパ腔は清澄・コルチ器は基礎回転には異常 を誌めないが、第2 回転の中央部におい、て外毛細胞核は 強〈萎縮濃染し中央のるのは消失する・胞体は腫振し て，下方ダイテルス細胞との境界不明となる・聴毛位認 められない、内毛細胞圷溷濁腫脤する・ダイテルス細胞 は腫脹し，ーンゼン細胞は萎縮するが，ともに核に著变 は無い、トンネル腔は清登で，神経線維は認められる。

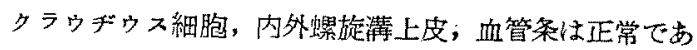

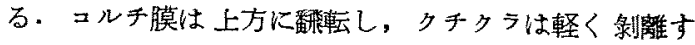

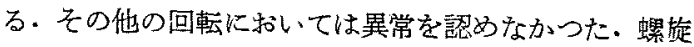
神経節細胞は全回転正常であつた．前庭迷路に異常は無 かつた.

44 号 (左側) 外耳及び中耳正常であつた。内耳蝸牛 迷路をみるに前庭階に少量の需絮状物質を認めた。ラ1 スネル膜は全回転正常である・コルチ器は第 2 回転全域 に亘つて变性像を認めた。即ちこの部つ外毛細胞は連脹 乙輪剠境界不明々なり，核は萎縮濃染し，変化の著しい 所で法消失寸る・ダイテルス細胞㤥は沈下して基礎膜上 に並び, ーンゼン細胞は萎縮して外毛細胞との間に大さ な空隙を作る・内毛細胞は胞体核とも澵縮する・外卜 ンネル線維は一部断裂するが膑内は清澄である・タラッ ギウス細胞，内外螺旋溝上皮は一部基底より脷離する。 螺旋縁では表面のクチクラ一部剝離するを認めたがンル 千蒖に異常は無い，血管条は正常・ローゼンタール管， 螺旋神経節細胞に異常は認好られない.その他の回転に 認もべき異常所見は無かつた・内耳前蓬迷路の各細胞は 正常であつた。

44 号 (右側) 外耳及び中耳儿異常無く，内耳の鎘牛迷 路は一般に清邆であるが，一部に出血の認められる所も あつた・コルチ器もみるに,この例では比較的広範围, 即ち第 1 回転終末部より第 3 回転起始部侸つて著明な 
变性破買像が認められた。その程度は第 2 回転比央部に 执いて最も大きく、ェルチ器はその固有の形態を全く失 い，藍にトンネル線稚の一部を判別し得るのみとなる。 基礎膜下細胞は核の配列乱れる、クラウデゥス細胞, 内 外螺旋㩐上皮は境界不鮮明で，胞体は眯となり染色性不 良で，核は菱縮し不規則な配列を示す コルチ膜，螺㳬 緑泟常.ライスホル膜は㮖に前庭階え向つて伸展して いる・血管条で特記すべきは毛細管の著明に抬磭なるこ とで，一見大空胞を形成せるが如くなる.これらコルチ 器及び支持細胞の变化は上下回転に近付くにつれて次第 に軽度となるが，これに随伴して血管条の变化も平行し ているのは與味をひいた。ローゼンタール管内神経細胞 はや>䠅となり，螺旋神経節紬胞は一部胞体の軽度萎繀 するものもあるが，チグロイドは正常で，核にも異常無 く，染色性良好で著変をみない.その他つ回転に異常を 認わなかつた。前庭迷路は全域に亘り正常であつた。

IIJ 界示投与終了後 3 週間飼育し筸響刺钱 (2000cps 110phon 毎日 2 時間連続 10 日間) 穵負荷した群

A) 臨床所見

全身状態には著明な影響を認めず，体重は実験開始前 上り一段に増玑し，第 2 次対照群と大美無からた。実験 終了後 3 日目のプライェル耳取射より作成したオーギ オゲラムは第 2 图の如く，一般に水平型万至は 4000cps 以上の高音域の低下する像を示した。回転後眼振による 前庭機能検查では常に何等の琣常を認めなかつた。
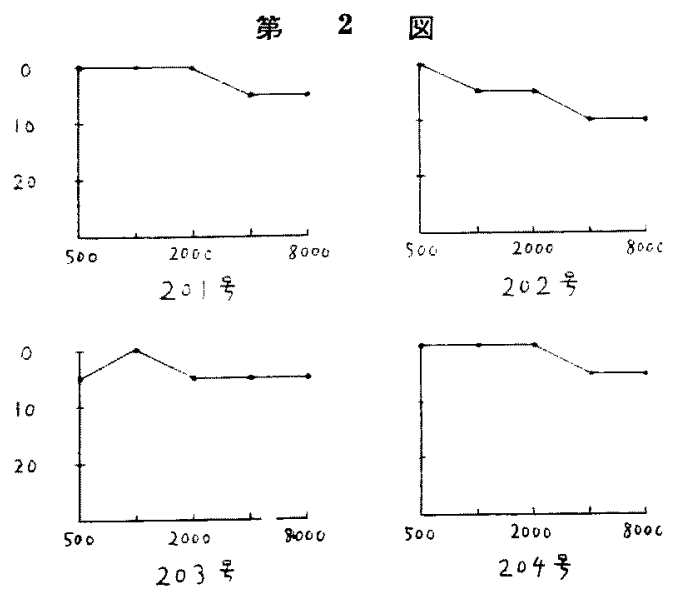

B) 聴器の病理組織学的所見

201 号 (左側) 外耳及び中耳には異常を認めなかつた。 内耳蜩牛迷路では内外リンパ腔清澄である・コルチ器は
基燃回転に異常を認めないが，第 2 回転中央附近の外毛

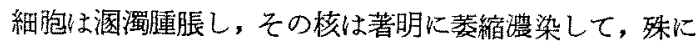
内側のるのは消失する・ダイテルス細胞、ヘンゼン細胞 は蕾脹し境界不鮮明となるが核に著変は無い、内外柱は 軽く屈曲する・トンネル腔は清登で神経線維は存する。 クラウデゥス細胞，内外螺旋清上皮には著变を認めな

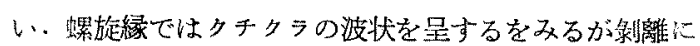
は至らない.コルチ膜, ライスネル膜, 血管条は正常で あつた・第3回転以上に翼常は認められない，螺旋神経 節細胞は全回転正常であつた，前庭迷路も正常である。 202 号 (左側) 外耳と中耳は正常である。内耳蝸牛迷 路では，第 2 回転に占いて前庭階に少量の雲絮状物質を みる他著変を認めない、コルチ器第 2 回轱中央部に特暴 な変性破壊像を認ぬた。破壊の高度な部ではコルチ器は 完全に消失して基磷膜上に抽ける扁平な無構造物と化 し,クラウデウス細胞，内螺旋瑇上皮に続くこれより 上下゙回転に向 5 につれ破擐の度は軽くなり，基磪膜上に 丘状あるいは半球状に集積した一群の相瓳合せる塊とな りな执軽度の部では，外毛細胞，ダイテルス細胞上部 が脱落消失し, ヘンゼン細胞, 網状膜及び內毛細胞にて

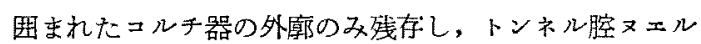
腔は合一して新たな大トンネル膑を非成せる如き観を呈 す，勿論腔内神経楾維は消失し，聴毛も認められない。 基喽膜下細胞は柾となり配列が乱れる、クラウヂゥス細 胞，外螺旋溝上皮は相互の境界不鮮明となり，胞体は

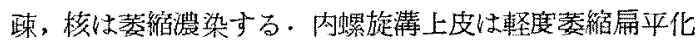
する、螺族緑，コルチ膜，ラィスネル膜に著変は無い 血管条の毛細管は拉張する・螺旋神経飭細胞は一部胞体 の軽度箖縮し細胞膜との閒に僅な空傹を生するるのもあ るが，テグロイドの配列に巽常無く，核は正常で，染色 性も良く著变を諗めない，基礎回転及び第3回転上上に は異常を認めない．前庭迷路は正常であつた。

202 号 (右側) 外耳及び中耳に異常は認められなかつ

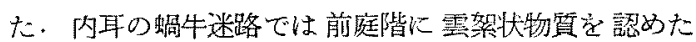
が，その他は清登であつた・基整回転にお゙いてコルチ器 は全く正常であつたが，籍2回転において外毛稩胞は润

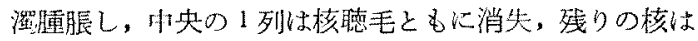

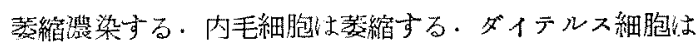

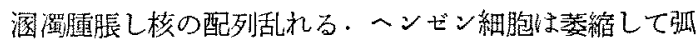
状となり核は濃染する。内外柱は軽く屈曲し，外柱の上 部は消失する・トンネル腔内神経線維は土存在する・基礎

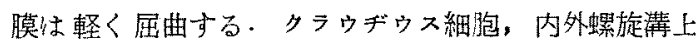
皮，螺旋縁，コルチ膜，ライスネル膜，血管条に著变は 
無い、螺旋神経節細胞には全く異常を認めなかつた・第 3 回転以上に波異常を認めない，前庭送路諸細胞佉全て 正常であつた。

203 号 (右側) 外耳，中耳恃正常.内耳蝸牛迷路で仕 内外リンパ腔清澄で, フィスネル膜は各回较異常無く, コルチ器第 2 回転のみに変性像を諗めた。盯ら外毛緗胞

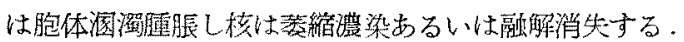
ダィテルス細胞，ヘンゼン細胞とるに腫脤し境界不鮮明 な集塊となる・内外柱，トンネル膑下の基酸膜は軽く屈 曲するが，腔内清澄で神経線維住認められる。付毛細胞 は萎縮する・タラウヂゥス細胞の一部及び肉螺旋溝上皮

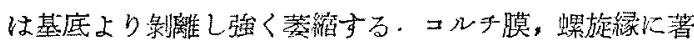
変は無い、血管条の毛細管は据張する・螺旋神経節細胞 は正常であつた・前庭迷路心買常は認められない。

204 号 (左側) 外耳及び+耳には病变杂諗めなかつた。

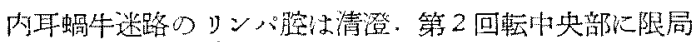

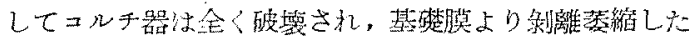

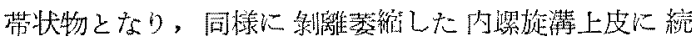

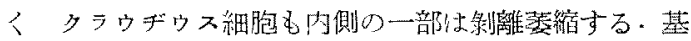

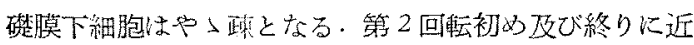
い部ではこれより变化少く，即ら外毛細胞は融解消失し て空洞を形成し，がィテルス細胞，ヘンゼン細胞は润濁 腫脹して相互に融含し，核は㶅染して配列乱れる。内柱 は屈曲し，外柱は破壊されてトンネル腔とヌェル腔は連 絡する・腔内神経線維は認められない内内毛細胞佉強く

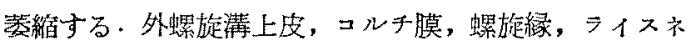
ル膜には著变を認めない，血管条の毛細管は搪張する。

ローゼンタール管内神経細胞に著变無く，螺旋神経節紬 胞は一部胞体の軽度萎綰する圶諗めたが，チグロイド正

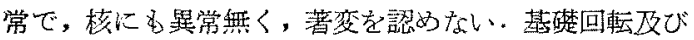
第3回転以上には全く異常を認めなかつた・前庭迷路は 全く正常であつた。

第 2 項 カンタリヂン投与群

この群にはカンタリギン投与終了後 3 日目より音響刺 战 (2000cps 110phon 每日2時間連続10日間)を員何 した。

A) 隐床所㫕

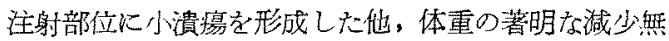
く，第 2 次対照群同稳全身状態には著变をみなかつた。 奏験終了後 3 日目に测定したプラィェル耳企反射から作 成したオーギホダラムは第3図の如く，一般に高音漸塗 型を示した。回転後眼振には終始異常を認めなかつた。
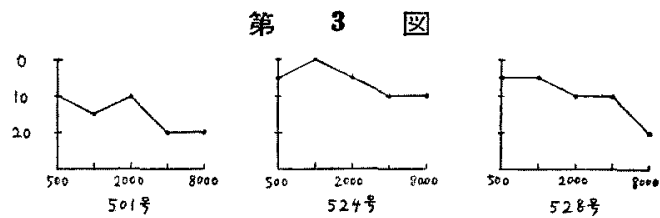

B) 聴器の病理組織学的所見

501 号 (左側) 外耳, 中耳正常、内工蜩牛迷路は内

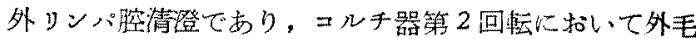

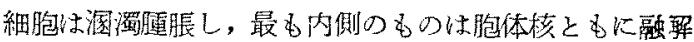
し,この部法空洞状となつてヌェル腔トンネル腔に連絡 交通する・ダィテルス細胞は柾となり境傫不鮮明でそ の最も内侧のものは外毛細胞と入もに融解する・ーンぜ ン細胞は腫脹し，その核は消失する。付毛細胞には著変

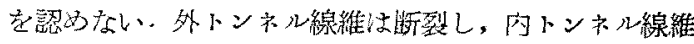
及ざ基楚膜仗屈曲する・腔勺神経線維仗詔められない

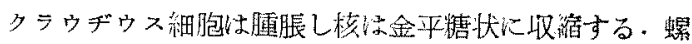
族緑，コルチ膜， いローゼンタール管，螺旋神経節細胞以は異常を被め なふつた・その他の回転は正常でおる・前庭迷路にも異

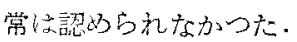

501 号 (者側) 外耳文び中耳に晎常は無かつた。内耳 螖牛迷路は内外りンパ腔清登である。ニルチ器は第 2 回 転に扮いて変性像を認めた。即ち外毛細胞は著明に溷濁 蕾脹して，下方がィテルス細胞との境界不鮮明となり， 核は崩解寸前の相を呈す ダイテルス細胞，へンゼン稩

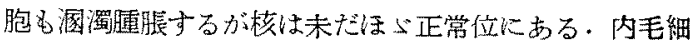

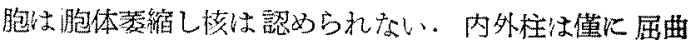

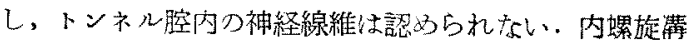

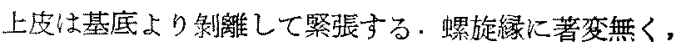

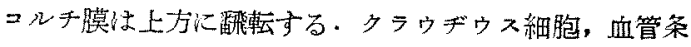
怔常・ラィスネル膜は波状となる・ローぜンタール管，

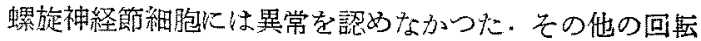
は正常である・内国前庭迷路の諸細胞にも異常は無かつ t心.

524 号 (左則) 外耳及び中耳儿在異常埾認好ない，内

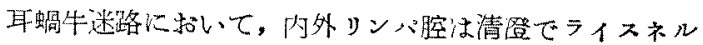

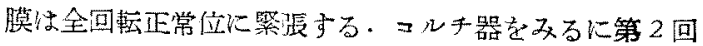

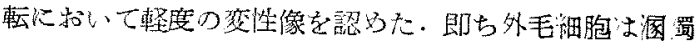

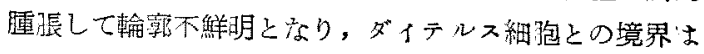

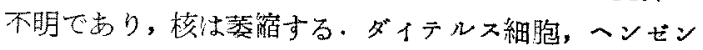
紬胞ともに腫掁し核は濃染する・内毛細胞も尰掁する。

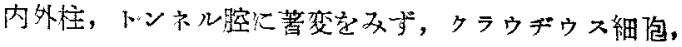


内外螺旋溝上皮の核は配列乱机不規則となる. ニルチ

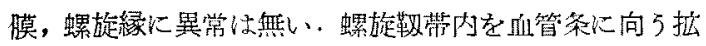
張した毛細管が㤎められた。螺旋神経節細胞は全く正常 でする.その他の回昙に黑常は無い.前庭迷路は正常で あつた

524 号 (右側) 外耳及び中耳正常であつた。内早で は, 蛤牛迷路のリンパ腔清澄でラィスネル膜にも翼常を

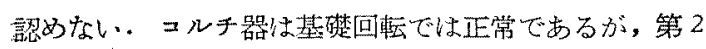
回蔭中央部に和いて最の内側の外毛細胞が消失し，外側

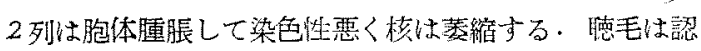
められない. ダィテルス細胞, ヘンゼン細胞は腫脹し 所な小空胞状となり，核は配列が乱れる・内毛細胞は消

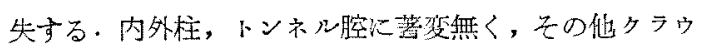

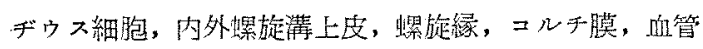

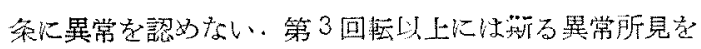
みない，前庭速路は全城全く正管であつた。

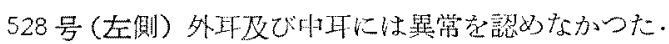

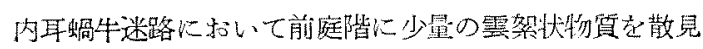

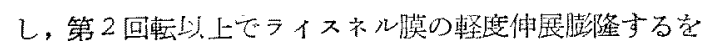

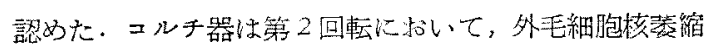
し胞体の一部融解して虫食状となる。ダイテルス緗胞は

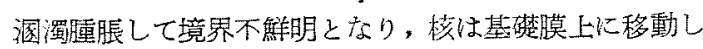

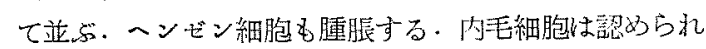
ない・トンネル腔は正常・タラウヂウス細胞は境界不鮮 明となり，核の金平艁状に双絠するを認めた。内外螺旋

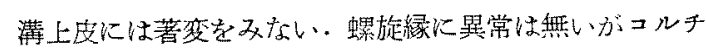
膜は反転举上しライスネル膜に密接する・血管条に著変 は無い.螺旋神経節細胞に異常は㒛好られなかつた。そ の他の回転は正常である・前庭迷路に認むべき巽常所見 は無かつた。

528 号 (右側) 外耳及び中耳は正常でおつた。内耳螖 牛迷路はリンパ腔清澄であるが, ラィスネル膜は上方回 転に打いて僅に上方へ伸展膨隆する。コルチ器は第2回 転に㤈いて，外毛細胞，ダィテルス細胞，ーンゼン細胞

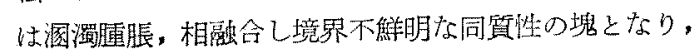

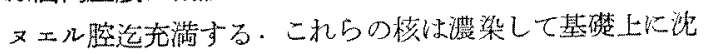

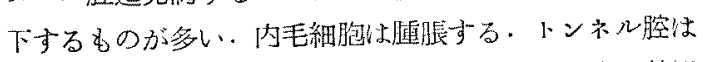
清登で神経線維は諗ぬら机る。タラウデりス細胞，外蟔

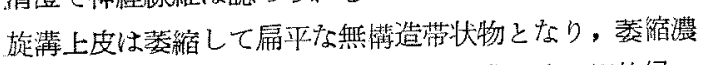
染した核の散在するを望めた。内螺旋瑇上皮，螺旋縁， コルチ膜, 血管条に著变は無い.螺旋神経節細胞に異常 は認められなかつた・その他の回転は正常である。前庭 迷路は全域に亘り異常所見を諗めなかつた。

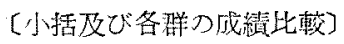

德器つ病理組織学的所見として, 全例炕心て外耳及

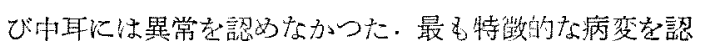

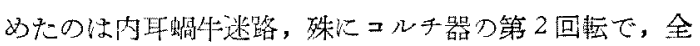

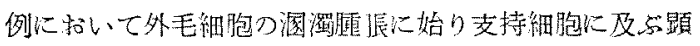

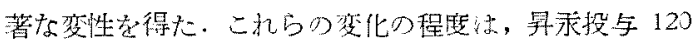

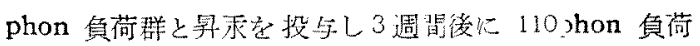
した群との間炕大美器く，いずれる上述の通り朋かな变

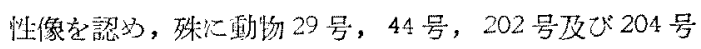

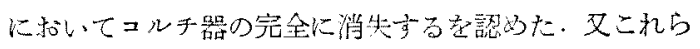

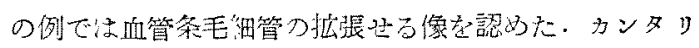
デン投与培に、ては，一般に界承投与群よりその変性

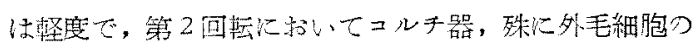

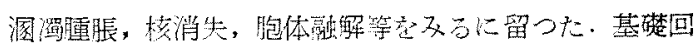

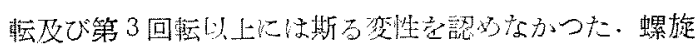

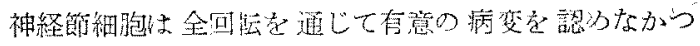

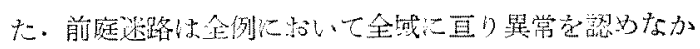
つた・第留終了後プラィェル上介反射上り作成したォー ヂオグラムは、こ札らコルチ礔の变化た大凡一致した。

第2 節 肝障㧹, 音響鿓荷羣

第 1 項 四盐化炭素投与群

I) 凹塩化炭素投与䅂了後 3 日目上り音第刺战 (2000cps 120phon 2 封間, 䧣日10回) 老 真荷した群

A) 臨床所見

体重の軽度減少与るるの古引，又2，3注射局所に潰

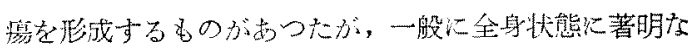

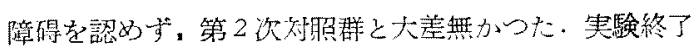
後3日目に测定したプラィェル耳介反的によるオーデオ ダラムは第4图の如き低下像を示した、回転後眼振には 異常を認めなかつた。
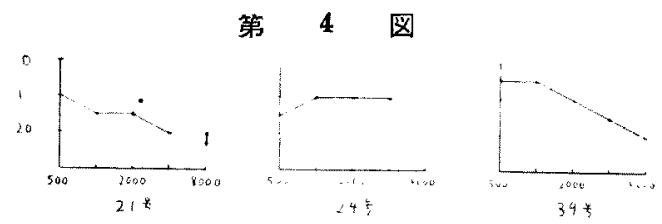

B) 渎器の病理組織学的所見

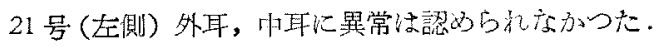
内耳蝸牛迷路の内外リンパ腔は全く清澄でラィスネ几胡

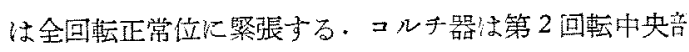

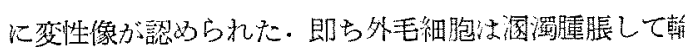

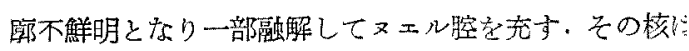


内側 2 列消失し，外側のものは强く萎縮濃染する、ダイ テル・ス細胞は蕾脹し境界不明, 同質性になり, 核は殆ん

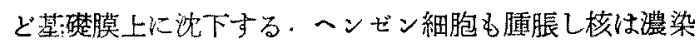
する.内毛細胞は輸廊不鮮明となり核は叙紑する。内外 柱は属曲し、トンネル腔はヌべクラにて充满されてい る・これら諸細胞の变化によりコルチ器は全体として一 塊の細胞群の如き観を呈す クラウデゥス細胞, 内外螺 旋溝上皮は胞体柾となり淡染して, 核は配列乱れ消失す るものもある・基礎膜下細胞は蹯となる・螺旋縁、コル チ膜には異常を認めない，血管条の毛細管は㹡張してい る・ローゼンタール筞は正常であり, 螺旋神経節細胞に も暴常は想められながた，その他の回転に異常は認め られなかつた，前庭迷路は正常であつた。

21 号 (右側) 外耳及び中耳は正常であつた．内耳蝸 牛迷路は内外 ッンパ腙一般に清澄であるが，一部シィス ネル膜上に微量の雲䋈状物質を認めた，第 2 回転中央部

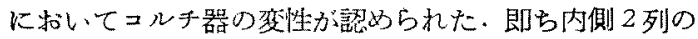
外毛細胞は融解して諗められず，外側のるのは胞体腫脹

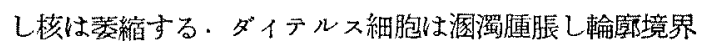
不鮮明となり，核は漶染して不規則な配列を示す ヘン ゼン細胞も軽店腫脹するが核に異常は無い、内毛細胞は 腫脹する、クラウデゥス細胞, 内外螺旋泟上皮は胞体眯 となり，核は金平觡状に収縮する・螺旋縁，コルチ膜， 血管条淁著变は無い・ラィスネル膜は僅に沈下する。口 一ゼンタール管内神経細胞はや」疎となるが配列に異常 は無い、螺旋神経節細胞は一部胞体が軽度萎縮し, 細胞 膜との間に小空隚を生ずるものもあるが，チグロイドは 正常で核にも異常は認められず，著变をみない，基跣回 転及び第3 回軽以上には異常夌認めなからた。内耳前莛 迷路は全域に亘り異常無加つた。

24 号（右㑬）外耳及び中耳正常.内晍牛迷路の 内外りンパ腔は清澄で, ライスネル膜は全回転正常位に あり、コルチ器は基碟回転及び第 3 回転以上には何等病 变を認めないが，唯第2 回転に軽度の变性像を䜑めた。 即占内側 2 列の外毛細胞分融解し，外側の外毛細胞は胞 休朠脹し核は装編する、ダィテルス細胞, ヘンゼン細胞 は相互の境界不觯明となるが核には著変をみない、内毛 細胞に著变は認るられない，その他の支持細胞にも著变 は無い，螺旋神経節細胞恃正常であつた，前庭迷路には 臀常を䛄めない。

39 号（右側）外耳，中耳に江異常を認めない内耴 蝸牛迷路は内外リンハ柾清澄である・コルチ器をみるに

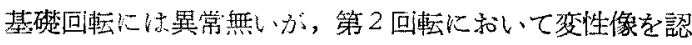

めた．即ちこの部の外毛細胞は胞体腫脹融合して一塊之 なりヌェル腔トンネル䐋も一部充たし，核は全て消失す る・ダィテルス細胞, ヘンゼン細胞, 内外柱細胞等も㴚 濁腫脹して外毛細胞と融合し，核の多くは沈下して基:

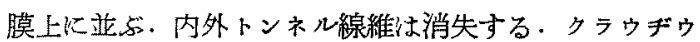
又細胞，外螺旋溝上皮は表面凹凸不平，境界不鮮明とな り，核の配列が乱れる.内螺旋㩐上皮も同㴍所見を示 しそその表面とコルチ膜との間にヌベクラを折出する． 螺旋縁，血管条偣変を認めないが，ライスネル膜は僅 かに沈下している、第 3 回転上上には異常を認めなかつ た。螺旋神経節細胞は全回転正常であつた，前庭迷路は 全域に亘つて異常を認めない。

II 四塩化炭素投与終了後 3 週間飼育し，音響 刺战（2000cps 110phon 毎日 2 時間，連続 10 回）を負荷した群

A) 臨床所見

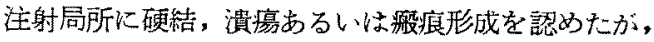
全身的には著变を認めず，藥郕投与中一眝娍少した体重 は飼育中に回復し，多くは策験開始前より增加を示し た・実験終了後 3 日目のプライェル耳介反射より作成し たオーデオグラムは第5 図の如き低下像を示したななする 回䎐後眼振では異常を示さなかった。
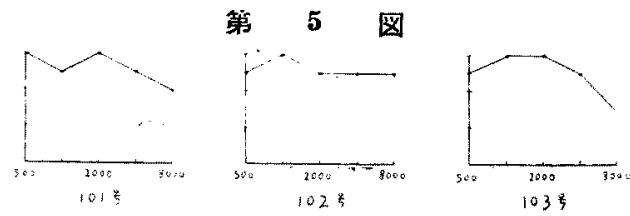

B) 聴器の病理組織学的所見

101 号 (左側) 外耳及び中耳には異常を認めなかった。

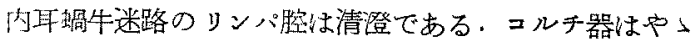
広籍国に，即方基碟回転終末部より第 2 回転終末部に亘 つて㚆性するを認めた。その变化の軽度な所では, 名毛 細胞の溷濁腫脹，一部融解して核の消失寸るものあり，

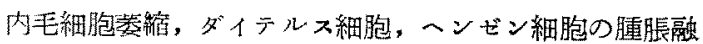
合，核の沈下家認め，变化の最子著しい所では，内外毛 細泡の消失，バィテルス細胞，ヘンゼン細胞，トンネル

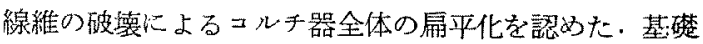
膜下細胞の配列は乱れる。クラウギウス細胞の一部及び 内缧旋满上皮恃基底より剥離萎縮する・螺旋縁, コルキ

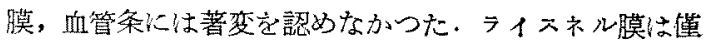
に上方へ膨隆する ローゼンタール管内神経細胞及で螺

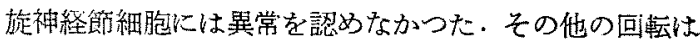


正常で斯る変性を認めない. 前庭迷路は正常であつた。

101 号 (右側) 外耳, 中耳儿異常無し. 内耳, 内外y ンハ腔清澄であるが，フィスネル膜は各回転少しく沈下 を示す コルチ器は第2 回転中央部に批いて交性するを 認めた，即ち外毛細胞は腫脹し，殊に中央のむのは融犖 消失する：ダイテルス緗胞る腫涱し，核の沈下を認め た.へンゼン細胞は輪遊不鮮明となる・内毛細胞は強く

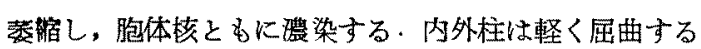
が腔内清澄で神経線維仕諗められる・クラウデウス細胞 はーンゼン細胞に隣接する部に扎いてて基底より汮離し萎 縮する、内螺旋溝上皮は全体儿基底上り剝離萎䋧し，直

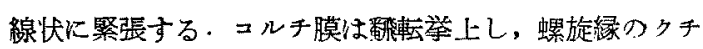
クラは波状を呈する・血管条の毛細管は抎張している。 螺旋神経節細胞火異常は認められなからた，その他の回 転は全て正常であつた．前庭迷路諸細胞には何等の異常 を誌めなかつた。

102 号 (右側) 外耳及び中耳には巽常を認めなかつた。 内耳螖牛迷路のリンパ腔は全域清澄であつた。コルチ器 は基磷回転に異常を認めないが，第 2 回転に扣い、て外毛 細胞殊火内側 2 列は強く浮腫状に腫脹し, 下方ダイテル ス細胞との境界不明となり，核，聴毛ともに消失する。 ダイテルス細胞、ーンゼン細胞は腫脹淡染し核の消失す るものがあつた・内毛細胞は萎縮する・外トンネル線維 は屈曲し, 膑内神経腺維は断裂する。内螺旋海上皮注基 底より剝離する、クラウヂウス細狍は眯となるが，螺唗 縁、コルチ膜に異常は無い.血管条に話いては毛細管の 相当に㹡張するを認めた。ロービンタール管, 螺旋神経 節細胞に異常は無かつた。第3 回転以上には異常所見を みない，前庭迷路に想もべき病変は無かつた。

103 号 (左側) 外耳及び中耳正常であつた。内耳蝸 牛迷路では内外リン八胵清澄であるが, ライスネル膜は 上方回転において僅かに沈下する・コルチ器は基礎回転 及び第 3 回転以上洪常無く第 2 回転中央部に限局し て变性破壊像を認めた。即ちその变化の最良甚しい所で は、コルチ器の原形を留めずクラウデゥス細胞に連続し た一置の扁平な同質性物犋と化し内螺旋溝上皮洛行す る、それより上下回転に近付くにつれ漸次破堎の度は軽 く、ヘンゼン細胞, 網状膜, 内柱及び内毛細胞等よりな るコルチ器の外形を保つたま〉, 外毛細胞, ダイテルス 細胞，外柱等の消失した大トンネル腔を形成するもの， あるいは外毛細胞とこれに接するダイテルス細胞の一部 のみ脱失し, その他俚比較的 ルルチ器本来の姿を保つる の等，種々の與味ある变性像を示す、基碟膜下細胞忙
や柾となる.内螺旋溝上皮仕僅に基底より娳離する。 クラウデゥス細胞もーンゼン細胞に隣接する部で萎縮す る、しかし乍ら, 螺旋縁, コルチ膜, 血管条には著変 を認めなかつた・螺旋神経節細胞には何等の病变を認め ず，前庭迷路も全域正常である。

第 2 項 エチォンン投与群

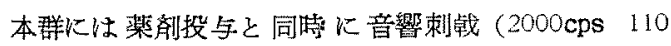
phon 毎日 2 㭙間, 連范10日間) を負荷した

A) 臨床所見

全身状態は，腹腔内注射と音響刺㦸を同時に行つた めか, 私の実験群中では最も悪く，運動不活發で元気を 失い, 体重は軽度乍ら全て娍少した，注射局所《は異常 を認めなかつた・実験終了後 3 日目のプライェル耳介反 射より作成したオーデオグラムは第6図の如く，一般に 高音部の反応低下を認め, 殊に動物第 405 号, 413 号 は8000cps に括いてプライェル耳取射の消失するを認

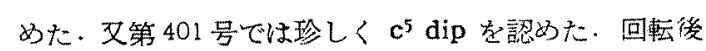
眼振による前庭機能検查では終始異常を認めなかつた。

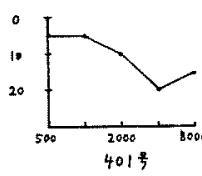

第 6 図
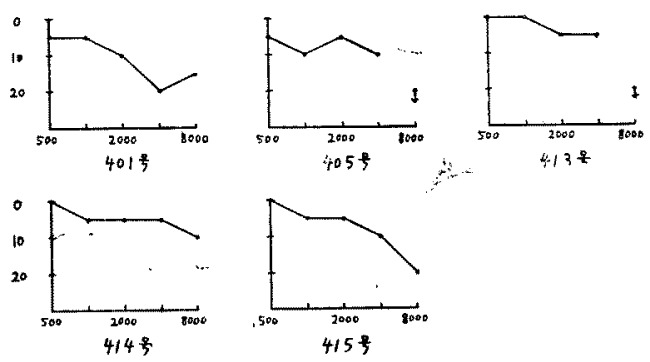

B) 聴器の病理組織学的所見

401 号 (右側) 外耳及び中耳に病変々認められる所見 は無かつた.内耳瀜牛迷路の内外りンパ空清澄で, コ ルチ器をみるに第2 回転全域に亘つて变性像を認め心。 即ち外毛細胞は内側 2 列が核消失し崩解寸前つ状態とな

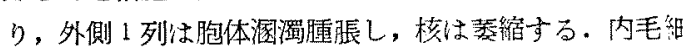

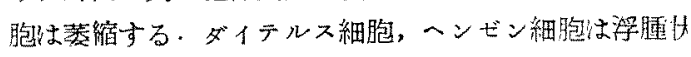
に腫掁し，染色性も悪く核の配列は乱れる・タラウ ヂウス細胞怯軽度腫脤し，内側の一部引基底上り剶離す

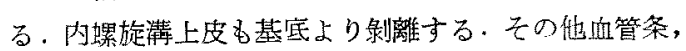
ライスネル膜, コルチ膜, 螺旋縁には著变を認めない。 螺旋神経節細胞に異常は無からた。年の他の回転には疤 的所見を認めなかつた・内耳前庭迷路は正常であつた。 405 号 (右側) 外耳, 中耳に病的所見は認められな力 


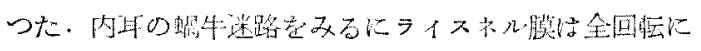

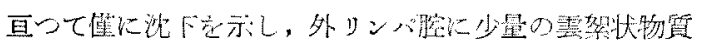

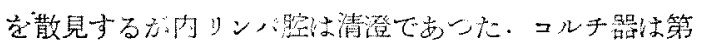

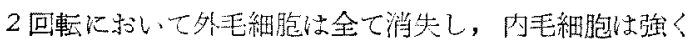
萎縮する・ダイテルス細胞，ヘンゼン細胞も脚体の一部

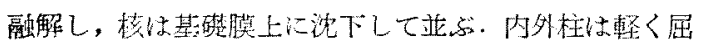

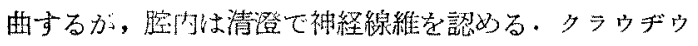

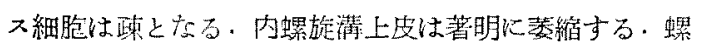
旅緑，コルチ膜，血管桑に著变を認めない、基础回転及 び第3回転以上は正常である。螺旋神経節細胞は全回転 に亘り何等の病的異常所見夌認めなかつた・前庭迷路は 正常ですつた・

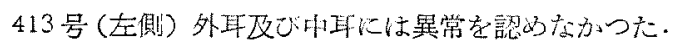

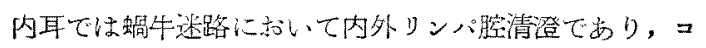
ルチ器は基碟回転及び第3 回転以上飞基常を認めず。第

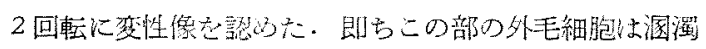
腫脹して核，聴毛乞もに消先し，ダイテルス細胞，つン

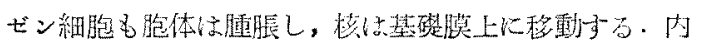

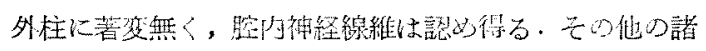

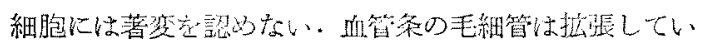

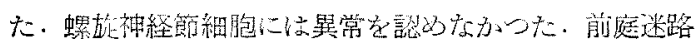
は正常ですつた。

413 号 (右側) 外耳及び相正常であつた。内耳蝸

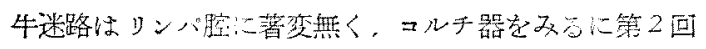
転に㧍いて，外毛細胞，ダィテルス細胞，へンゼン細胞

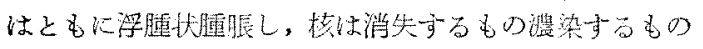

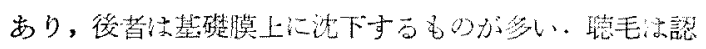

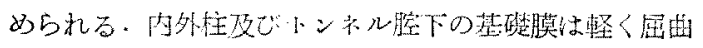

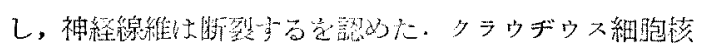

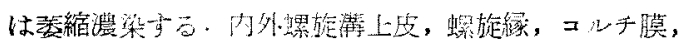

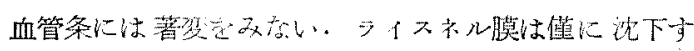

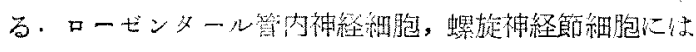

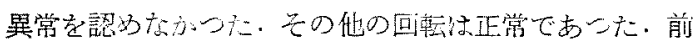
庭迷路は全垠に旦つて異常所兒をみなかつた。

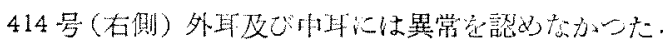

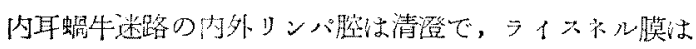

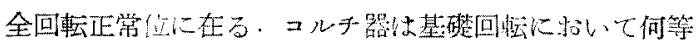

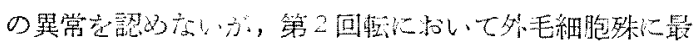

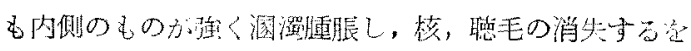

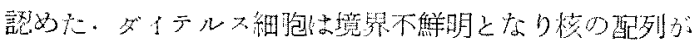

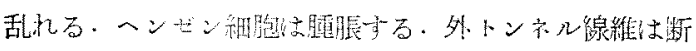

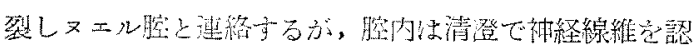

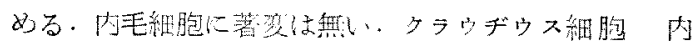

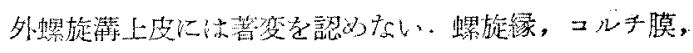

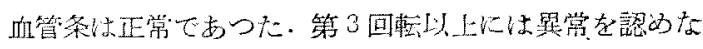

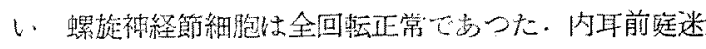

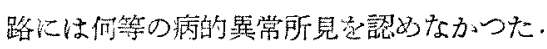

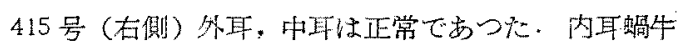
迷路において内外リンパ点は大凡清登であるが，ライス

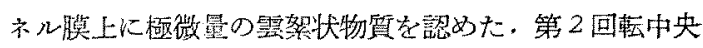
部に扣いてコルチ器の空坐するを婄めた。即ち外毛細胞

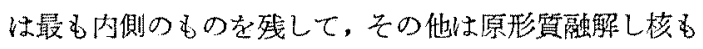
消失する・ダィデルス細胞、ヘンゼン細胞は腫脹して承 となり,核は浸染して不规則な配列老示す 内毛細胞に 著变结無い、内外柱㤬轻く屈曲する・トンネル腔は清澄

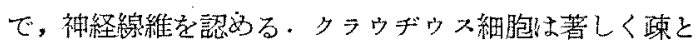

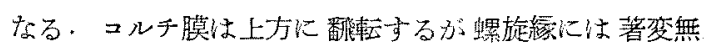
く，直篦条も正常である、ロービンタール管内神経細胞，

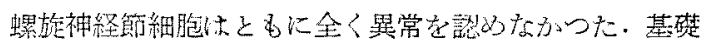

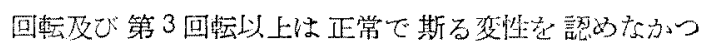

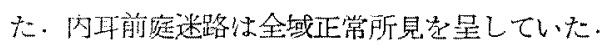

[小括及び各群の成縝比較]

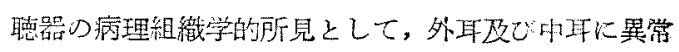

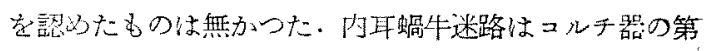

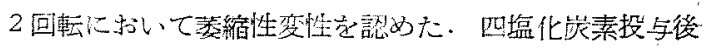

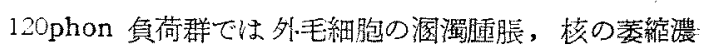
染治まり，や>顕著なるのでは胞体の一部融解消失，

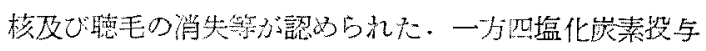

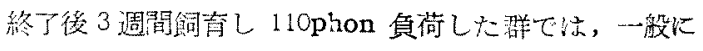

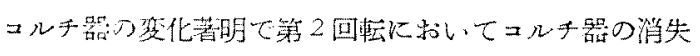

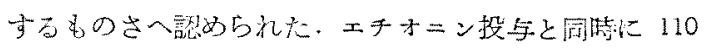

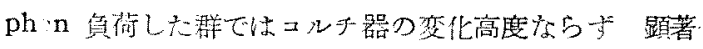

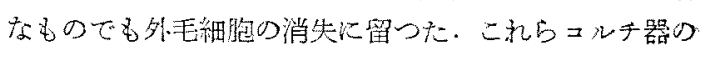
変化第 2 回転に限局し，その优の回転には灭ばない。

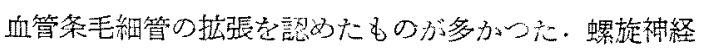
節細胞には病的異常所見を热めず，全て正常であつた。

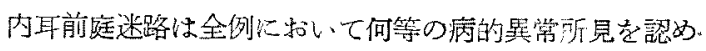
なかつた・垁験終了後ブライエル耳取射より作成した オーヂオダラムは概ねコルチ器の変性に一致を示した。

\section{第 5 章 総括並に考按}

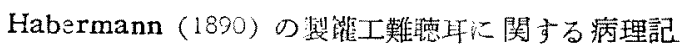

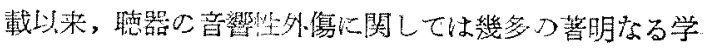

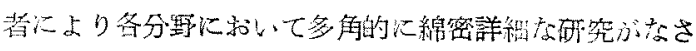

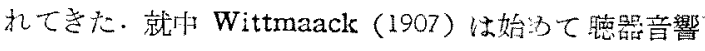

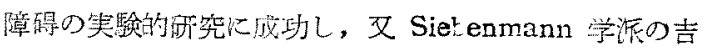

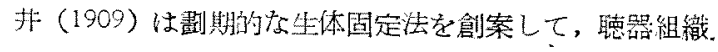


病理の研究に貢献すること大なるるのがあつた，その後 v́. Eicken, Hcessli, Marx, Grünberg, Röhr, Popoff, 松井, 内田, 木村, 岡崎, 竹沢, 松浦, 河田等比上り研 究が続けられ，その業績にはみるべきるが多いしいか し1940年頃迄は，その研究方法は単純て，使用された

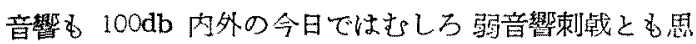
えるものであり，徉つて実験的に恥器の音響障碍を招来 せしむるには極めて長時間の曝露が必要であつた。

しかるに今㳄大戙勃発以来, 各稙近代重工業亚に新兵 器の発澾に伴い, 更に强大なる音響暴らされる㻟威に 遭遇するの余儀無きに至つた・これに呼応して，実験に 使用される音響毛強大となる一途を巡り，丽機工業心進 歩により各種音響発生装置が考案され，現今では Rüedi, Furrer, Davis, Lurie, Hawkins 等炕よれば，140

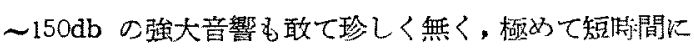
聴器の永久的障碍を䓺起せしむることさえ可能となつ た.

又病理組繶学的研究によらずとも Microphonics そ つ他聴賞電気生理の発展によつて, 聴覚渡労に関する諸 研究にも改る゙きものが多い。

しかし乍ら，これ等の実験的研究はいずれも揵康動物 に就いてなされたものであり，騒音にせよ純音にせよ音 管刺韩と云う一外因的要素による聴器障碍であつて，実 医対象たる個体にある内因的要素，即ち何等かの疾患乃

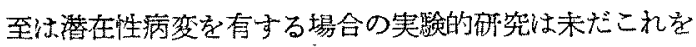
みない。

周知の如く，これ迄取上げられた臨床、上の観察におい、

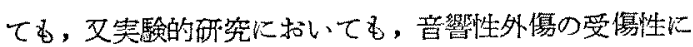
は甚しい差が認められていたが，徒来単に個体差と称せ られ，これについて今日迄積極的にとの原因が追求され たことは無く，従つて未だその解決をみない状態であ る・往来音響障碍の実䍄的研究にあたつて使用された動 物は，個体に既に何等かの疾患を有するものは全て除外 されるのが常であった・しかて乍らこつで観点を変光， 現在聴器に何等の異常を認めなくてもそれ自体既に難聴 をきたし得る疾患を持つた個体に就いて音響受㑥性の变 化を究明するのも肝要なことつ云放将な゙ならない。

即ち聴器以外の他器官にあるい、恃全身的㳊等かの病 変，異常がある場合に㯖力障碍の生じ易いことは古来交 献に散見する所であり，又想像するに難くない，各種疾 患々難聴との関係を文献上儿求をれば，先つ血液疾患儿 物いては白血病患者に難聴を訴劣るものあり, Vidal, Isambert, Politzer, Schwabach, Gradenigo, Alexan- der. 田所，三岛气の他多数の報告例をみる．Haberma.

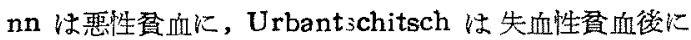
瑟となれる例を報告している・新堜代謝疾患では，糖尿 病 (Edgar, Robin), 痛風 (Erbstein, Scheibe, Wolff heim）に，内分泌腺疾患では粘液水䐈，クレチン病 (Alexander, Bloch, Robin) 飞難聴老伴うものがある。 ビタミン久方症, 殊に $\mathrm{B}_{1}$ 久乏症と難㯖には密接な関係 があり, 脚気患者の難聴例飞就いて漂井, 伎藤, 石松, 安孫子、久野等の報告老及る, 又下平, 長野, 小野, 安孫 子等は実験的に $\mathrm{B}_{1}$ 欠之状態として難㯖の発現するを証

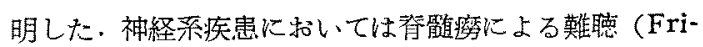
edlich, Voigt, Burger, Gradenigo, Marie, Walton) があり, その聴器病理の記載 (Baratoux, Berthold, Strumpell）尚るる.消化器采疾患では, Wolffheimは 周病殊火胃潰瘍, 肝硬変, 慢性便秘, 僄延性黄誼等は難 聴の原因たり得ると述へ，更に Robin は爾牙，扁桃， 虫垂、胆霍等の疾患もこれ火加觉ている・菊池（三）は 神経性難聴者の多数に肝機能障碍を認め,肝機能の改善 により㓡力の回復するを報告した・泌尿器疾患中殊に腎 障碍と聴器疾患に密接な関連のあることは古くより認め られて招り，就中急性腎炎の経過中に原因不明の難聴を 併発し‡例は極めて多く, Dieulafoy，Moos, Morf, Doumerque, Rosenstein, Grahe, Mann 等の報告があ る.特に浮腫の出現, 消退と入もに難聴の增悪, 軽快を

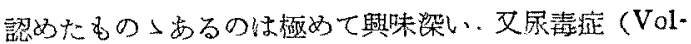
hard)，慢性腎炎（Wittmaack）に拈いてと進行性の内 耳性難聴の発現がある・急性伝染病では猩紅熱の経過中 にくる中耳炎の他に神経性難聴が知られ，その他床柊， インフルエンザ, デフテリー、腸チフス等においいて同

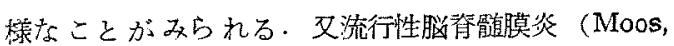
Voltalini, Leichstein, Agazzi, Birkholz), 流行性耳 下腺炎 (Gallavardin, Boot, Mauthner, Ruttin) 飞安 䧼聴を続発寸る・慢性层染病には結核, 梅毒があり, 後 藤（修）は原因不明の難聴者の家柔に結核の多いことを

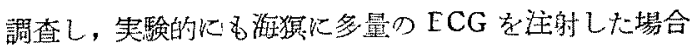
にブラィェル耳介反射の低下することを認妨、梅毒に

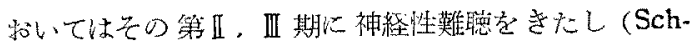
wartze, Gradenigo, Fournier, Oppenheim, 城户), 先 天性梅毒で彼の有名な Hatchinson's Trias の一つと して難聴が挙代られ, Siebenmann, Meyer, Alexander 等は年の聴器病理に就いて記载した。運動器疾患 中急性骨髄炎 (Siebenmann, Steinbrüger, Bloch, Castex, Wangenhäuser, Bezold, Schüller) に上る難 
聴例が報告され，関節口イマチス（Wolf），Paget 氏病 (Robin) 等が難㯖の原因たり得るとも云われる。難聴 をきたし得る葉物中䓯としてはキニーネ，サルチル酸， へハポデ油, 鉛, 水銀, 沃隻, ベンダール及びストレブ トマイシン等によるるのが举佔られる・その他アレルギ

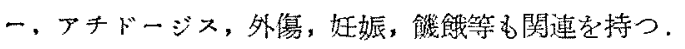

斯くの如く臨休的, 統棓的観察によれば, 聴器固有の 疾患以外で，而も咕器と何等かの関係学有する疾患のい かに多いか警く程であり，従来原因不明の難聴亡解され たものや、所謂個体差なる請葉で睖眣に表見されてきた

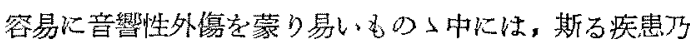
至は異常が潜在性に存したのではないかと云うことは容 易に想像され得る。

先に述べた如く，個体が既に何等かの疾患乃至は異常 を耳局所にあるいは全身的に持つ場合，その音響受傷性 がいかに変化するかに就いての彔統的研究は殆んど 無 く，僅に最近に至つて臨床面上り藤野（1950），土肥 (1953) は缸膜に驽孔を有する場合，高音域の㯖力障碍 が軽度であると述べ，更に土肥は鼓膜に著明な内陌，肥 厚、萎縮める埸合及び Pneumatisation 良好な場合に る，作業年数 15 年以下であれば聴力障碍の軽度なるこ とを追加した．田中（1952）は耳管開塞は連続騒音によ る聴器障碍に促進的に働くと述べた，一方全身的に異常 のある場合に就いて，Cook（1952）は内耳螖牛迷路の 所謂 Hydropsを発現せしむる条件，例へば食笽の過剩

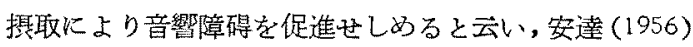

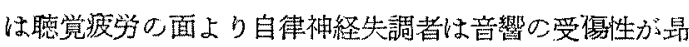
谁することを証明した，又音響により内耳障碍を蒙り易 い内的因子として, 藤野 (1950) は先天的素因, 難聴定 きたし得る全身疾患，薬削中毒，梅毒及び脚気等を，

Robin は消化器疾患, Hypothyreoidism, Avitaminosis, Allergic disorder, Niemann-Pick's disease 等 を挙げている・実験的研究としては，藤野（1948）によ るビタミン $B_{1}$ 欠乏食で飼育した白鼠で音響障碍の大な ることを証明したものと, 逆に原田（1956）がビタミン $B_{1}$ を注射しつ〉音薌負荷したが，聴器に殆んど障碍を 誋めなかつたものを知るに過ぎない，最近教室の经藤は 中毒量以下の悖器表投与動物に括いて，松原はレントゲ ン線职射動物においてて夫。音響受傷性の最淮するを試 明し，山川(愿) は自律神経遮断剂投与, 全身麻酤, 自 律神経毒投与等の諸条件下に音響受慯の 变化するを㒛

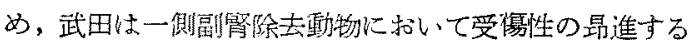
をみた。
斯く考察しきたれば，音響受傷性の研究には圆体に潜 在せる疾患するい惊常を考慮に入れず，外見上健康を 装つた人体あるい、動物を用いて、徒らに强大なる音響 をるつてするは甚しく杜撰な感を抱かしめる。それ故， 聴器の音響受甥性を昆進させ得ると推察される疾患乃至 は異常学選び，これを動物に奏験的に生ぜしる，斯る動 物に对して対照動切では聴器に何等の暴常を生ぜしめな い程度の音響剌㦸を鿓荷し、これによつてその受賃性の

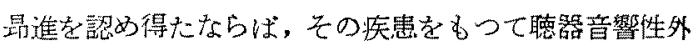
賃の内因的要素と見做し得るのではないであらうか，

斯召能点より，私は内因的要素となるべき疾患とし て，生命維持㵊も重要なる役割を演ずる警・肝の障碍 を選んだ．近年死因の第 1 位を占め，而る年々堌加の傾

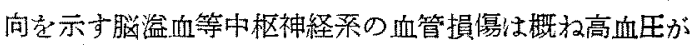
その原因であり，腎矤患とは密接な因果関係を有する。 一力肝疾患も最近各方面より注目される所となつた・耐

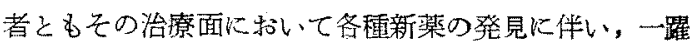

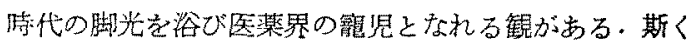
の如く近年多数の患者を擁し, 論䜋の的となれる腎・肝

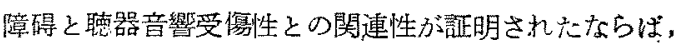
今日の如く各種の音翠刺战下に生活せざるる得ない、時代

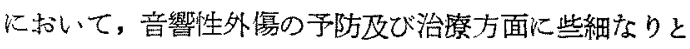
る示崚する所あれば章いなりと念じ，これを実験的に証 明せえと試みた。

前述の通り，先ず基礎的研究として傅庫海晖を用い， 臨床的主に病理組織学的に聴器に何等の異常をきたさぬ 程度の腎・肝障碍を实験的に与之，更にこれら動物に娃 して、これも单独では恥器に变性を招来しない程度の音 響刺戟を急荷した。

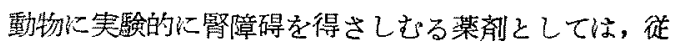
来用いられてきた年承及びカンタリデンを，䀒障碍には

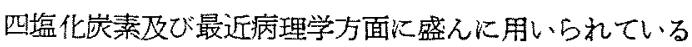
エチオニンを使用した・岡畸によれば，乐乘あるいはカ ンタリデン投与により繁障碍を起させた場合，とるに内 耳螖牛迷路においてコルチ器及び螺旋神経節細胞の全回 転に退行性変性を招来するるのである，四塩化炭素は

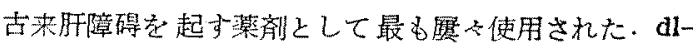
Ethionine ( $\alpha$-amino- $\gamma$-ethylmercaptobutyric acid) は Methionine の Antagonistであり，その作用とし ては肝細胞の变性, Fibrosis, 脂肪肝，細網内皮系の堌

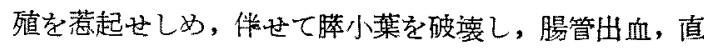
腸潰瘄を形成せしめる等が認められている・しかし乍ら， これらによる聴器変性を諗めた実験的研究は未だこれる 


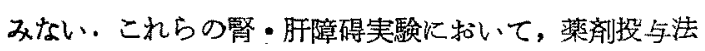
には細心の注意を払い, 松井 (1926), 岡崎 (1928), 守 田(1955), Farber, Weser, Popper (1951〜2) 等の実 験を参绍にし，腎・肝には病理組織学的に異常を生じ乍 ら・而も聴器には何等の晎常所見を認めない投与量を決 定した・その投与法は第3章に述べた。

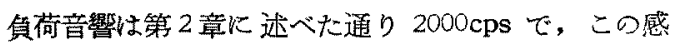
受部位はコルチ器第 2 回転にあり，その強度は，単独で は聴器に病理組織学的に異常を生じないことを礁諗した るのを用いた。

腎・肝障碍，音響負荷群の成續は第 4 章に这べた通り であるがこつに総括すれば，界承単独投与群では腎障碍 を生じ乍らも聴器に何等の病理組織学的変化を認めず： オーギオグラムる正常であつたが、これに 120phcnの 音響を負荷した群では、コルチ器第2 回軽において外毛 細胞に始まり，支持細胞に及んで，遂にはコルチ器の完 全消失に至る变性像を認めた。しかし乍らこの变化は $2000 \mathrm{cps}$ 感受部位に一致して第 2 回転に限局し，基磷回 転及び第了回転以上には及ばなかつた，故に餐障碍のみ による聴器変性像ではなく，明かに音響による变化であ る・昇录投与終了後 3 週間飼育して音響負荷した群では 110phon の弱音響であり乍ら，コルチ器障碍の程度讷 120phon 群とほぶ等しく，コルチ器の完全消失を認め た例もあり，粲障碍の進行に伴い聴器音響受賃の内因的 要素としての影箩の大きいことを示した。

カンタリヂン投与群ではコルチ器の变性は軽度でらつ

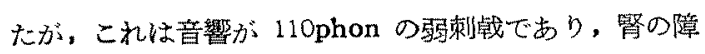
碍る軽度なるためと推祭される。

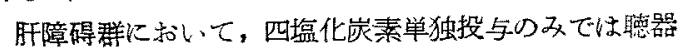
に異常を生じないに閣らず,これに 120phon の音響刺 战を偩荷した場合ニルチ器第2 回転に中等度の变性像を

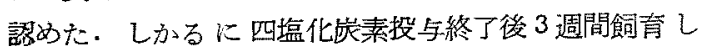
110phon の音響を負荷した群では, 肝障碍の進展に伴 いェルチ器に膏度の夜性を諰め, 区つて肝障碍の聴器音

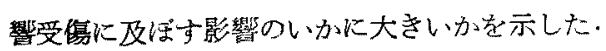

エチォニン投与群では四湓化炭素投与群に比しコルチ

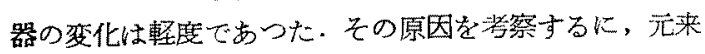
エォォンンの短期間投与では肝細胞破䏅作用は，雄動物 に执いては雌動物に比し極めて軽度で, 男性ホルモンの エチオニンに拮抗することが認められているので，本拣 験に括いても肝障碍の晫度なることは当然予想される所 であり，從つて聴器に及ぼす影䉥も軽度であつたものと 轧される、しかし乍ら実験当初，動物は全て雄を使用す
ることに決め統一したつめ，エチォニン投与群にも敢て 雄海犋安用いた・若し嚾であれば更に高度の变性像を招 来した日のと推察し得る。

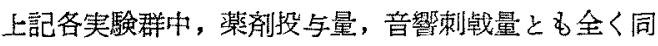
じであり乍ら，しかもな招一群中に泪体による若干の 差を認めた：この成績は私の丰䀫目的にそぐわないるの

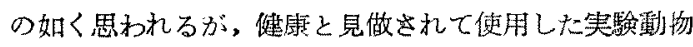

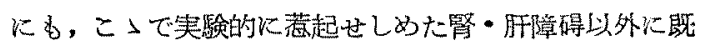
に何等かの潜在性病変が存在していたものと推測すれば 解釈され得る. 前述の如く内因的要素となり得べき疾患 乃至は異常に槧々多㴍なものが考えられるので, 斯くの 如き推則无甚しい:飛躍とは思は、れない。

緊・肝障碍時, 難聴の発現をみる原因として, 腎障碍

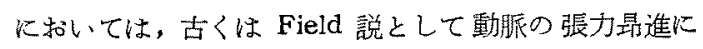
よる迷路内圷增進のためと云われ、 Rosenstein は恥神 紾の浮蕾のためと解した。これに対し Volhard は動振

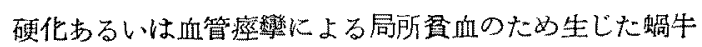
神経の迷路後性障碍で岕ると述べ, Wittmaack はアチ ドーデスによる中毒性血行性迷路変性ならんと云う. Wolffheim は (1) 离血任と血管壁の变化による Nephr osklerose から内耳血管系の変化觉招来，。(2) 聴神経の 浮庫，(3)アチドーヂスあるいは迷路出血による变性 考考えた。そ他 Blucke，Schwartze は中耳出血， Moos, Grawitch は中耳粘膜の肥厚等を唱えたが，ち れ等はこの際コルチ器に明かな病変を誌めた以上, 除外 さるべきであら5

一方松毛によれば肝機能障碍は (1)暚組織の呼吸及 び解艁に影響を与え，(2) Stammganglien に桨化をき たし，(3) 植物神経系の異常を抬来すると云われ，菊池 (三)は一次的に肝障碍が起り，これと聴力との間に一 定の関連性が存在して、肝機能の改善により聴力の回愎 し得る可能性を論じている。

又後藤（修）は原因不明の難聴者に，毛細管透過性の 珙常が多いと報告し，三宅は原因不明の所謂内耳性難聴 者及び実験的聴覚障碍動物に，䯣液，内年液のアミ，酰 減少と屈折摔の低下を認めた。

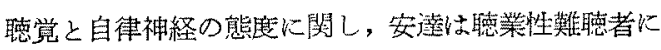
は自律神経機能状態に異常の放ることを諗め，莱池(三)

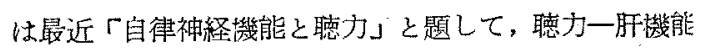
一自律神経系の関系に考繁索加えている。

これら先人の研究業績により, 聴器と血管系及び自律 神経系との間に密接な関係を有することは明かである。

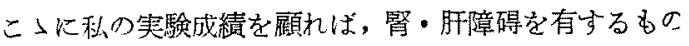




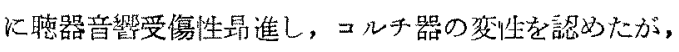
一方内耳的物迷路のみに目学移せば，コルチ器に中等度 以上の变性を認めた例流いては，摡して血管条毛細管 の扗張を热めた・この所見のみより断定するは叫か㪕率

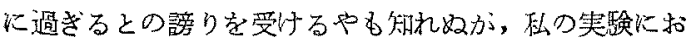

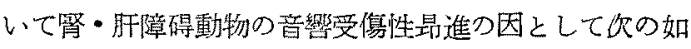

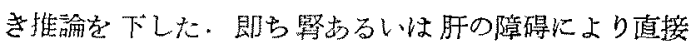
に，むるいは自律神経柔を介して間接に，内年血管腬に 何等かの影照を及ぼし,このため内耳液組成に变化を与

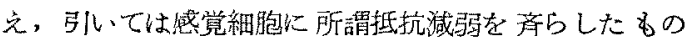
て, 斯る聴器障碍に好する隼确状態か一要因となつて潜

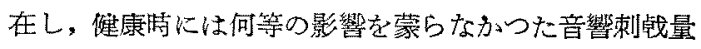
によつてる容易に障碍を受けたものと解せよう。

\section{第6 章 結語}

種々の菜削の一定量を非経口的に僬康海狽に投与する ことによつて, 聴器に病理組織学的変化をさたさない程

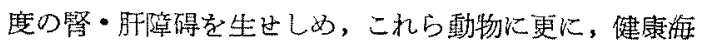

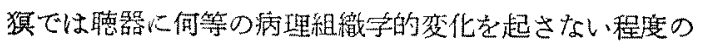

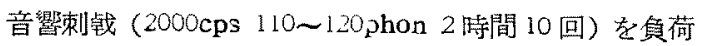
し, 次の結論を得た

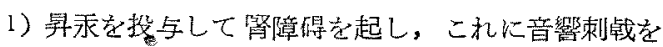
行つた場合に、コルチ器第2回転に执いて夜性を認め た。

2) カンタリヂン投与により管障碍を生せしめ，これ に音響刺㦸色真荷した塄合にも, コルチ器第 2 回䎐に变 性像を認稀た

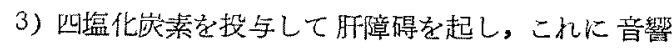

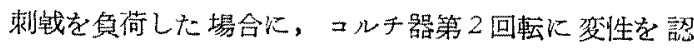
めた。

4）エチォニン投与によつて肝障碍を若起せしめ，こ

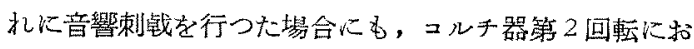
いて变性像を詔めた

5）内耳蜳牛迷路の基礎回転及ひ第3 回転上上に抎以 てコルチ器は正常て斯る变性を諗めず, 螺旋神経節細胞

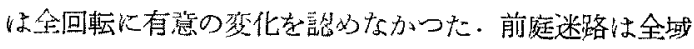
正常で岁つた。

6）ブライエル耳介反射は，主として 2000cps より高 音部に和いて低下を示した

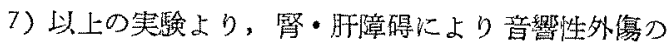
受傷性か昆進小ることを証朋した。

\section{主要参考文献}

1) Wittmaack, K.: Ueber Schädigung des Gehororgans durch Schalleinwirkung. Z. f. Ohren heilk.
54;37,1907 2) Yoshii, U.: Experimentelle Un tersuchungen über Schådigung des Gehörorgans durch Schalleinwirkung. Z. f. Ohrenheilk. 58; 209, 1909. 3) Marx, H.: Untersuchung uber experimentelle Schädigungen des Gehörorgans. $Z$. f. Ohrenheilk. 59; 333, 1909. 4) Hoessli, H.: Experimentelle erzeugte professionelle Schwerhörigkeit. Z, f. Ohrenheilk. 69;225, 1913. 5) Popuff, N.F... Zur Frage uber die experimentelle durch Schallreizung hervorgerufenen Veränderungen in der Schnecke. Mschr. Ohrenheilk. 57 ; 704, 1923 . 6) Horton, G.P.: An experimental study of stimulation deafness in gui nea-pig. Ann. Otol. Rhinol. \& Laryngol $44 ; 252,1935$. 7) Lurie, M.H.: The dege$\mathrm{n}$ ration and absorption of the organ of Corti in animals. Ann. Otol. Rhinol. \& Laryngol. 51 ; 712, 1942 8) Wheeler, D.E.: Noise-induced hearng loss. Arch Otolaryng. $51 ; 344,1950$. 9) Lurie, M.H., Davis, $H$ \& Hawkins, J.D.: Acoust 1 c trauma of the organs of Cort 1 in the gunnea pig. Laryngoscope 54 ; 375, 1944. 10) Rïedi, L. and Furrer, W.: Akustısches Trauma und Funktion des Innerohres. Acta. Otolaryng 33;460, 1945. 11) Rüedi, L. \& Furrer $W .:$. pecial kind of acoustic trauma produced by jet engines. Arch. Otolaryngol. 54 ; 534, 1951. 12) Sataloff, J.: Acoustic tra'uma in children. Ann. otol. Rhinol. \& Laryngol. 61; 106, 1952 13) Sataloff, J.: Effect of prolonged exposure to intense noise on hearing acuity. Arch. Otolaryngol. $58 ; 62,1952$ 14) Davis, H.: Acoustic trauma in the guinea pig. Jour. Acous. Soc. Amer, 25; 1180, 1953, 15) Hilding, A.C.: Studies on the otic labyrinth $(V)$ : The possible relation of the insertion of thetectorial membrane to acoustic trauma, nerve deafness and tinnitus. Ann Otol. Rhinol. \& Laryngol. 62 ; 470, 1953. 16) Riedi, L.: Different types and degrees of acoustic trauma by experimental exposure of the human and animal ear to pure tonss and noise. Ann. Otol. Rhinol. \& Laryngol. 63; 702, 1954. 17) Grahe, K.: Zentrale Hörstörunge.1 Z. f. Ohrenheilk. 6; 498, 1923. 18) Grahe, K.: Hör- u. Gleichgewich tsstörungen bei Nephritis. Z. f. Ohrenheilk. 8; 375, 1924. 19) 
Lederer, L.: Die nicht auf Mittelohrerkrankung beruhende Schwerhörigkeit bei Nierenkrankheiten. Lehrbuch d. Hals-Nasen-Ohrenheilkunde nach Denker, A. u. Kahler, W. 20) Robin, I.G.: Perceptive deafness. Disease of theear, nose and throat. II. 291. 21) Wolffheim, L.W.: Disease of the ear in relation to disease of other organs. Arch. Otolaryngol. 52; 157, 1950. 22) Farber, E., Weser, D.K. \& Popper, H.: The influence of sex and of the testosterone upon fatty liver due to ethionine. Endocrinology. 48;205, 1951. 23) Popper, $H$, Huerga, J. \& Koch-Weser: Hepatic and pancreatic changes produced in rat by ethionine and their relation to human lesions. Amer. J. Path. 28 ; 518, 1952. 24) Loring, W.E. \& Hartley, L.J.: The destructive effect of DL-ethionine on the pancreas, stomach and submaxillary glands. Amer. J. Path. $31 ; 521 ， 1955$. 25) 山川留四郎：生体固定法

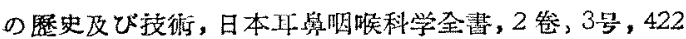

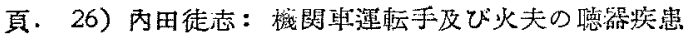
に関する実瞼的研究，福岡医点，11兊，2号，120頁，大

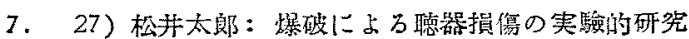

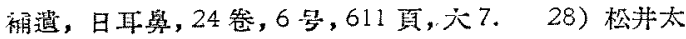

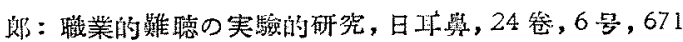

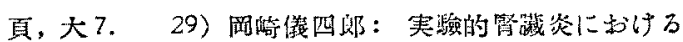

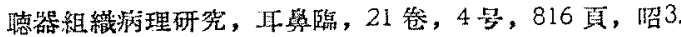

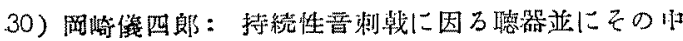

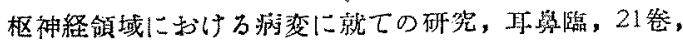

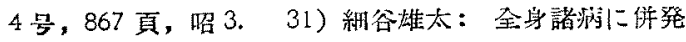

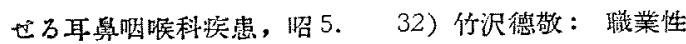

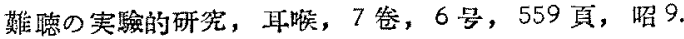

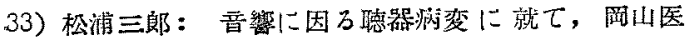
誌, 47 巻, 2 号, 279 頁, 炤 10.34$)$ 河田政一：䭽

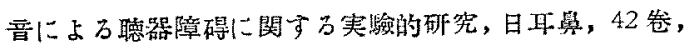

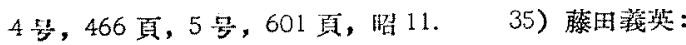

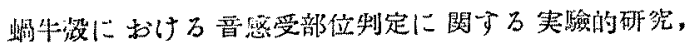
日正骨, 47 参, 6 号, 806 頁, 炤 16.36 ) 元山微:

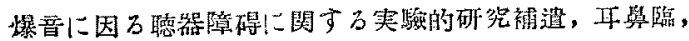
36 卷, 9 号, 845 頁, 昭 16.37 ) 村上三郎: 㯖神経

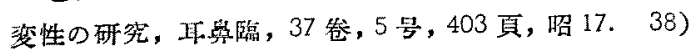

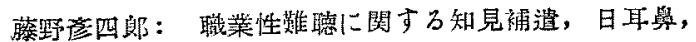

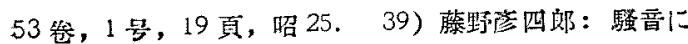

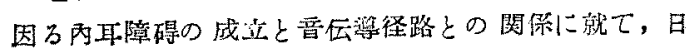

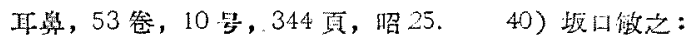

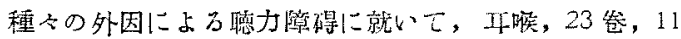

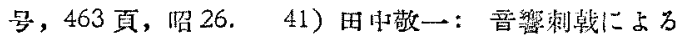

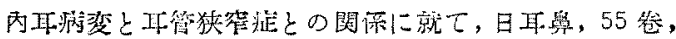

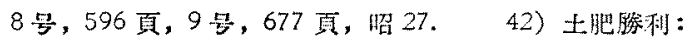

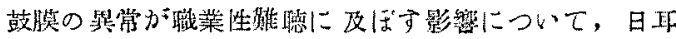

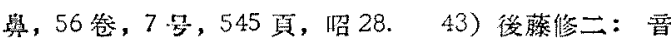

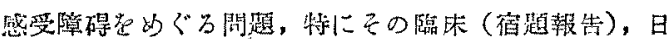

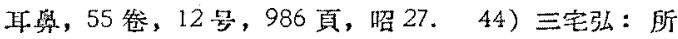

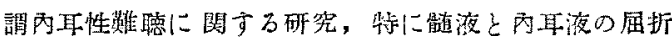

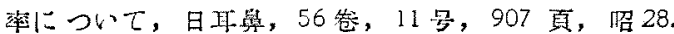

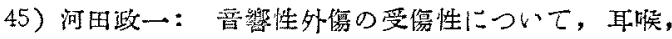
26 卷, 13 号, 575 真, 炤 29.46 , 窲湖三通男: 耳

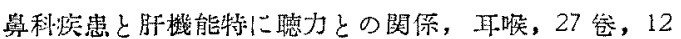
号，45面，炤30４４）宇口悲：ストレプトマイシ

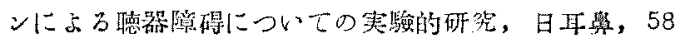

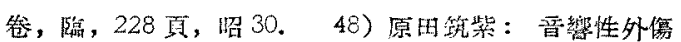

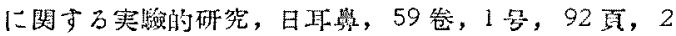

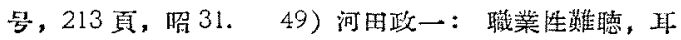

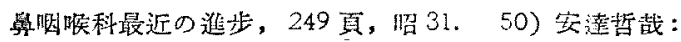

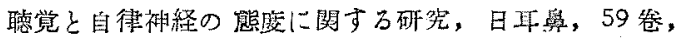
3 号, 408頁, 炤 31 . 51) 值藤武男：聴器毒投与動

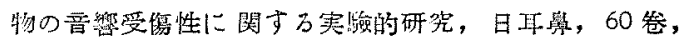

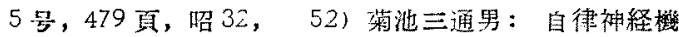
能々嚼力, 耳喉, 50 卷, 6 号, 28 頁, 紧 32 .

\section{写真説 明}

(1) 第 1 知刘照刑 (110phon)

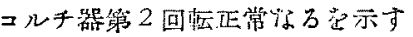

(2) 第 1 次対照群 (120phon) エルチ器第2 回乾正常礽ら觉示す

(3) 第 2 次対照称（曻永投与） 㨁紐尿管の变化党示す。

(4) 第 2 次対照程 (昇承投与) 明細尿管及び系正体の变化を示す

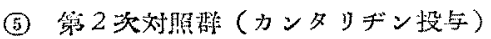

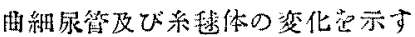

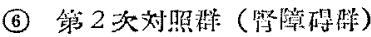

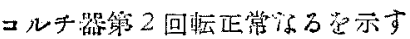

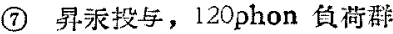

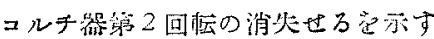

(8) 昇乘投与, 110 phon 真何程 コルチ㗊第 2 回忶の変性を示す 
(9)カンダリデン投与, 110phon 負街群 ニルチ器管 2 回転の装性を示す

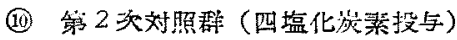
肝小葉队变化进示す

(11) 第2次対照群（エチォニン投与） 朋小策网の装化范示す。

(19) 第 2 次好照群 (肝陵碍群) コルチ器第2 2 回転正常な万宗す。

(13) 四塩化烧素投与, 120phon 負街群 コルチ知第 2 回転の变性を示寸.

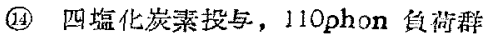
コルチ器第2回転の変性を亦す

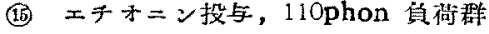
コルチ器第 2 回転の装性花示す

(16)內耳編牛迷路, コルチ器の装性は第 2 回転のみに限 局起宗永

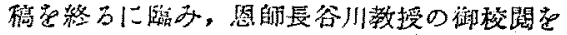

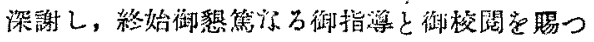
た吉田倣教授，佐藤助于及び阪大第一病萑理学教

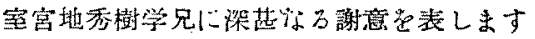

（原稿到艮＝怊和 32.8 .14 日）

\section{T M 3 號改良型ユニット}

電 源 室内電灯交流 100 ボルト

日立製 $1 / 4$ 馬力モートル

真空度 水銀柱 $760 \mathrm{~mm}$

圧力 $4 \mathrm{~kg} / \mathrm{cm}^{2}$

用 途 器㧴卓子・嵲瓶台・光源電灯

吸引・鼻洗深・鼓膜按摩

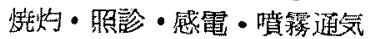

ネブフイザー

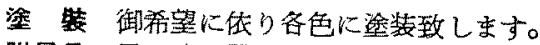

附屈品籍貲器 5 吸可管 1 組 蒜瓶活物年 2 支柱電灯 1 嘴管瓶 1 港綿子容器 2 感電渞子 1 組 鼓膜按摩器 1式 足踏メイッチ 1 算洗用嘴管 1 欧氏管カテーテル1組

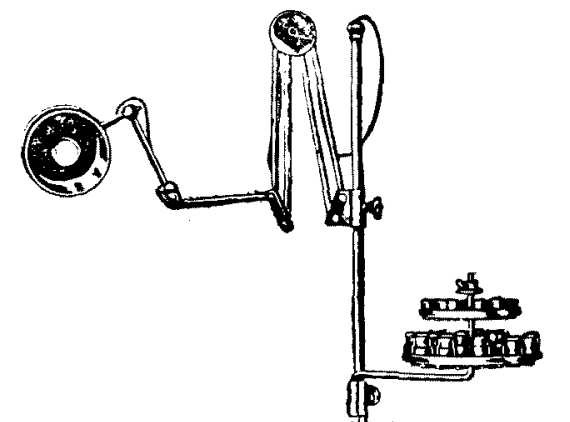

自悬咽喉科気管食㨁科医療器械 有 限会社

\section{T.M 醫療器松并憋作所}

身宗都交意区湯島二丁目四番地 管話 小石川 (92) 0575 番 1281 番 振謷口座 東袁 77409 番

京都市身山区身大路松澺下ル小鼠町 142

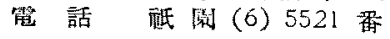

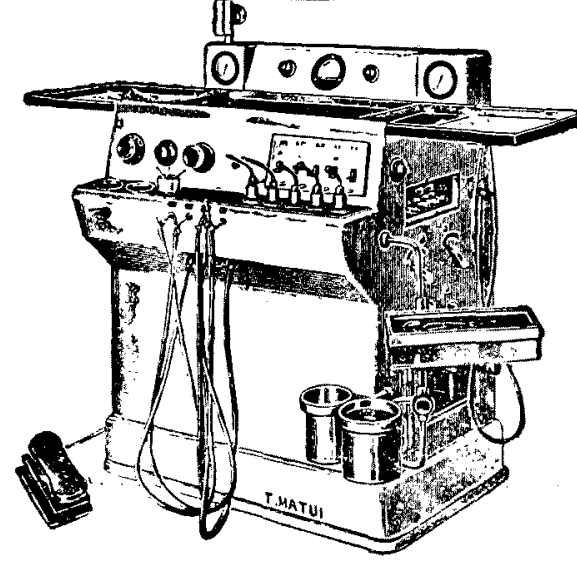


菊池論文附図（I）

(1)

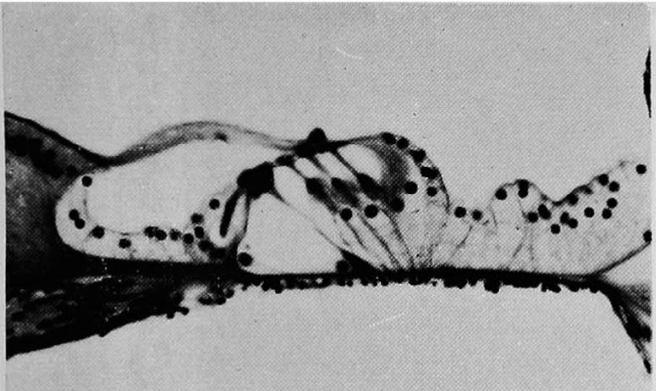

(3)

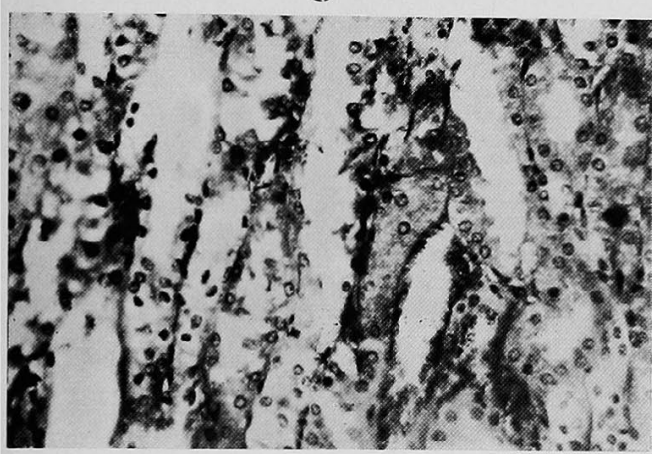

(5)

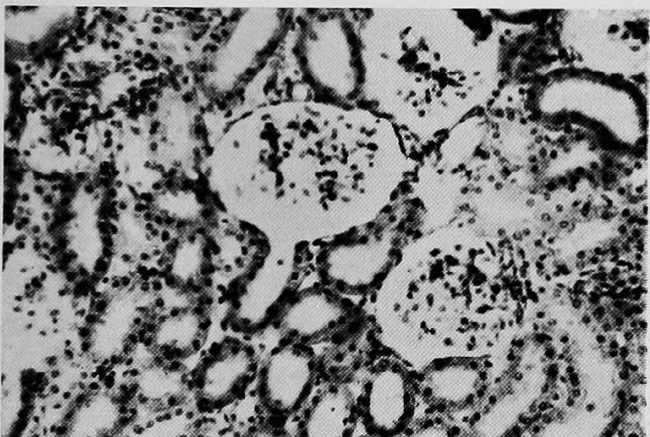

(7)

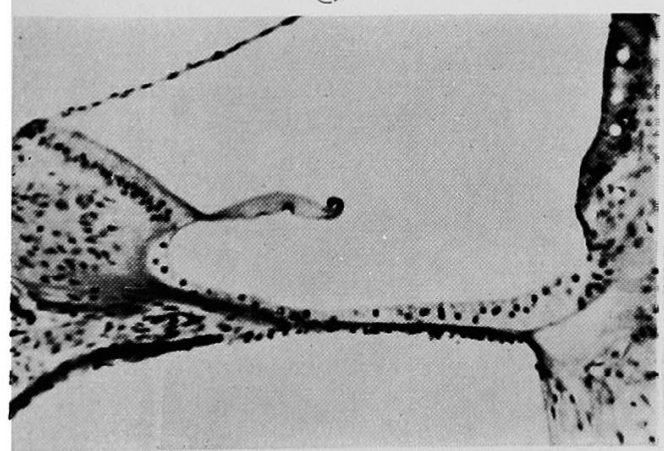

(2)

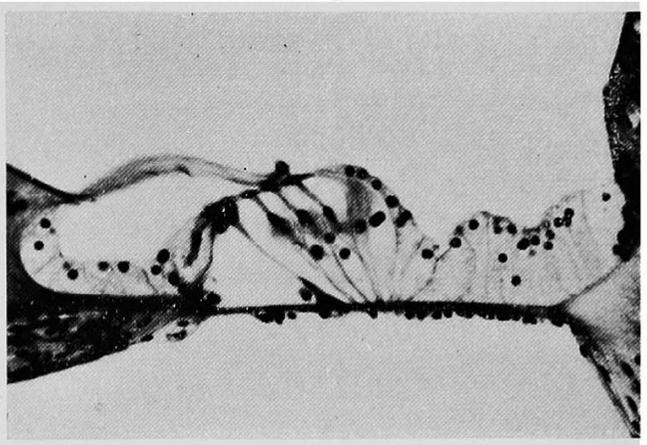

(4)

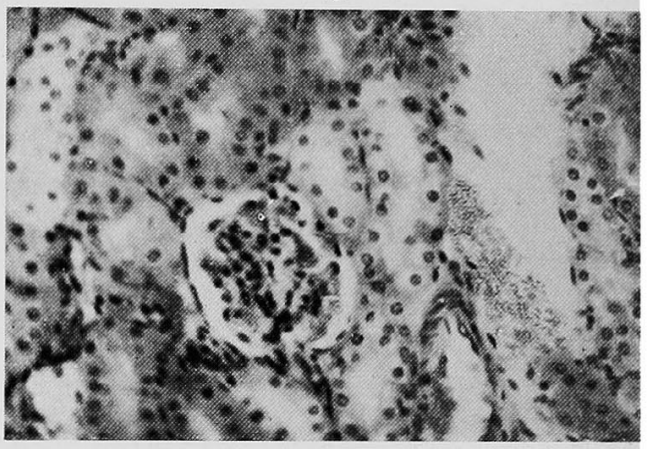

(6)

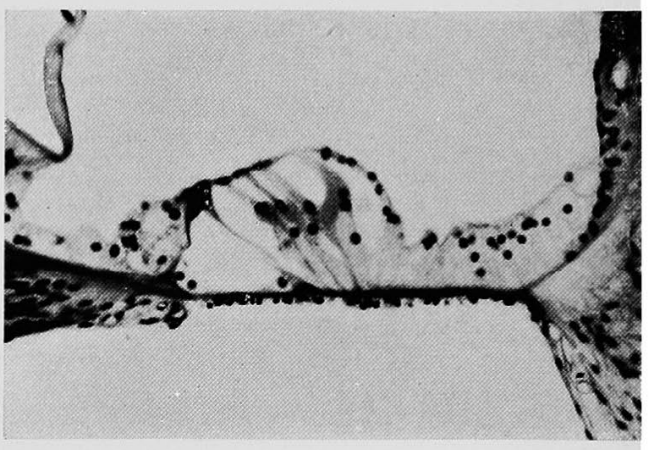

(8)

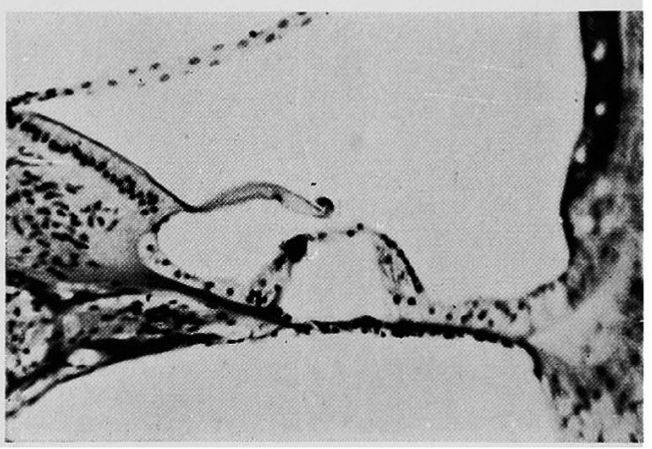


菊池論文附図（II）

(10)

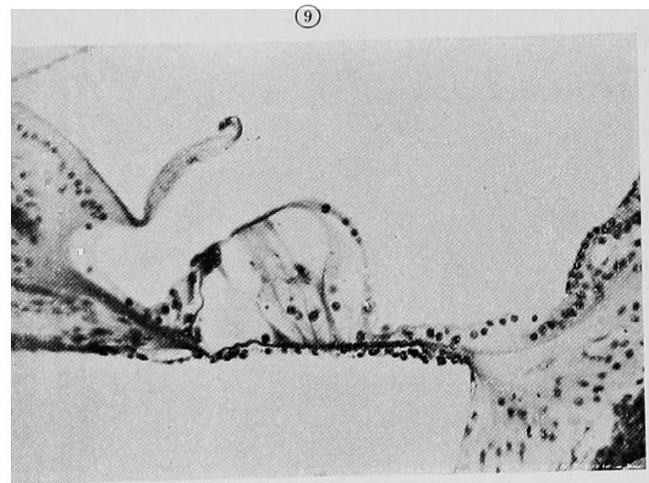

(11)
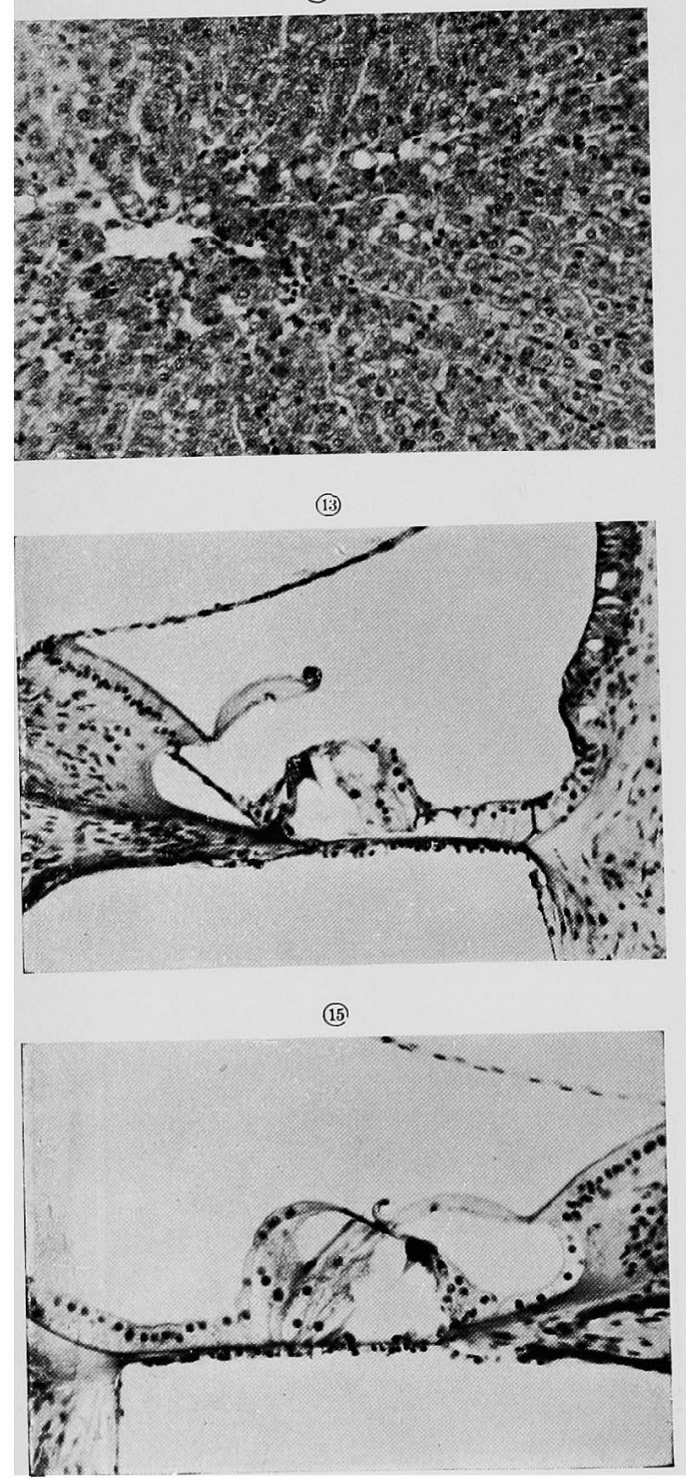

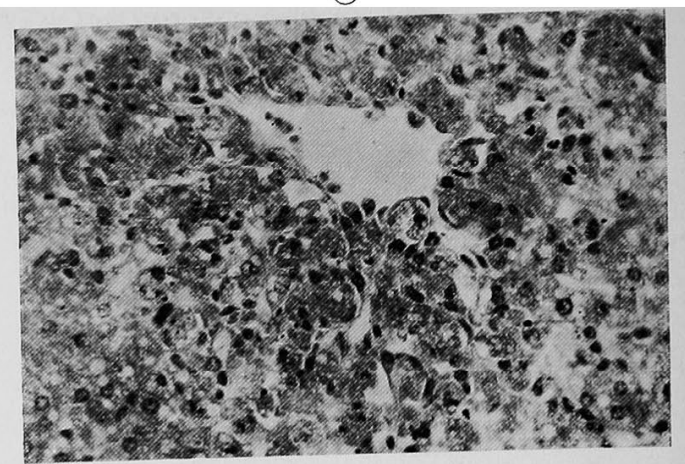

(12)

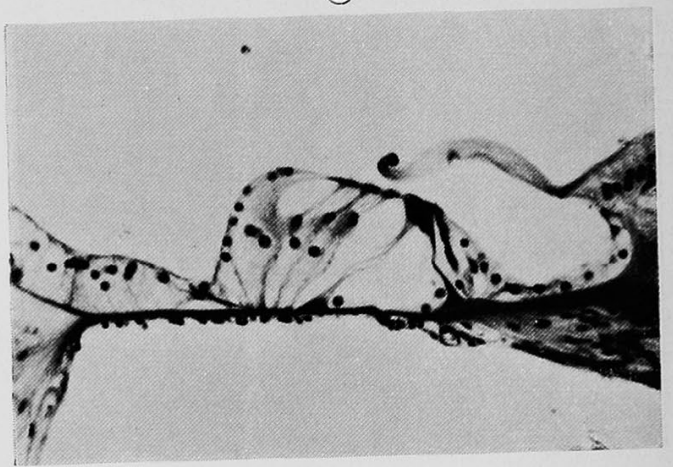

(i4)

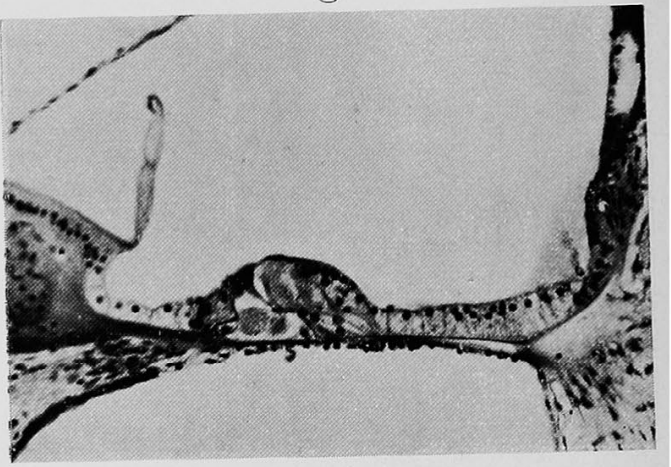

(16)

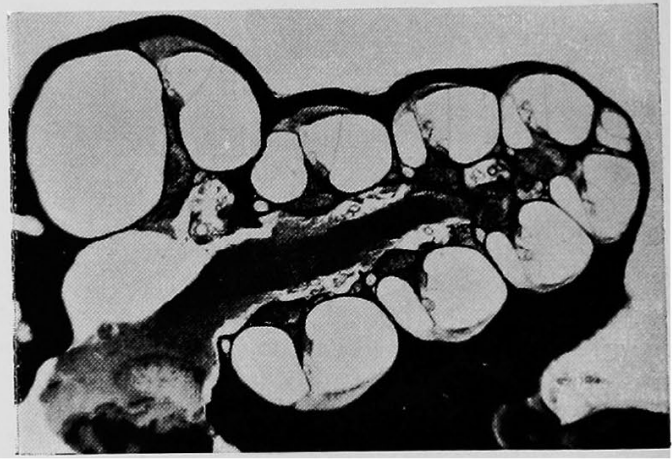

